\title{
Sulfate-nitrate-ammonium aerosols over China: response to 2000-2015 emission changes of sulfur dioxide, nitrogen oxides, and ammonia
}

\author{
Y. Wang ${ }^{1}$, Q. Q. Zhang ${ }^{1}$, K. He ${ }^{2}$, Q. Zhang ${ }^{1}$, and L. Chai ${ }^{1}$ \\ ${ }^{1}$ Ministry of Education Key Laboratory for Earth System Modeling, Center for Earth System Science, \\ Institute for Global Change Studies, Tsinghua University, Beijing, China \\ ${ }^{2}$ School of Environment, Tsinghua University, Beijing, 100084, China \\ Correspondence to: Y. Wang (yxw@tsinghua.edu.cn)
}

Received: 6 August 2012 - Published in Atmos. Chem. Phys. Discuss.: 17 September 2012 Revised: 31 January 2013 - Accepted: 10 February 2013 - Published: 5 March 2013

\begin{abstract}
We use a chemical transport model to examine the change of sulfate-nitrate-ammonium (SNA) aerosols over China due to anthropogenic emission changes of their precursors $\left(\mathrm{SO}_{2}, \mathrm{NO}_{\mathrm{x}}\right.$ and $\left.\mathrm{NH}_{3}\right)$ from 2000 to 2015 . From 2000 to 2006, annual mean SNA concentrations increased by about $60 \%$ over China as a result of the $60 \%$ and $80 \%$ increases in $\mathrm{SO}_{2}$ and $\mathrm{NO}_{\mathrm{x}}$ emissions. During this period, sulfate is the dominant component of SNA over South China (SC) and Sichuan Basin (SCB), while nitrate and sulfate contribute equally over North China (NC). Based on emission reduction targets in the 12th (2011-2015) Five-Year Plan (FYP), China's total $\mathrm{SO}_{2}$ and $\mathrm{NO}_{\mathrm{x}}$ emissions are projected to change by $-16 \%$ and $+16 \%$ from 2006 to 2015 , respectively. The amount of $\mathrm{NH}_{3}$ emissions in 2015 is uncertain, given the lack of sufficient information on the past and present levels of $\mathrm{NH}_{3}$ emissions in China. With no change in $\mathrm{NH}_{3}$ emissions, SNA mass concentrations in 2015 will decrease over SCB and SC compared to their 2006 levels, but increase over $\mathrm{NC}$ where the magnitude of nitrate increase exceeds that of sulfate reduction. This suggests that the $\mathrm{SO}_{2}$ emission reduction target set by the 12th FYP, although effective in reducing SNA over SC and SCB, will not be successful over NC, for which $\mathrm{NO}_{\mathrm{x}}$ emission control needs to be strengthened. If $\mathrm{NH}_{3}$ emissions are allowed to keep their recent growth rate and increase by $+16 \%$ from 2006 to 2015 , the benefit of $\mathrm{SO}_{2}$ reduction will be completely offset over all of China due to the significant increase of nitrate, demonstrating the critical role of $\mathrm{NH}_{3}$ in regulating nitrate. The effective strategy to control SNA and hence $\mathrm{PM}_{2.5}$ pollution over China should
\end{abstract}

thus be based on improving understanding of current $\mathrm{NH}_{3}$ emissions and putting more emphasis on controlling $\mathrm{NH}_{3}$ emissions in the future.

\section{Introduction}

Sulfate, nitrate and ammonium (simplified as SNA) are the predominant inorganic species of fine particulate matter with diameters less than $2.5 \mu \mathrm{m}\left(\mathrm{PM}_{2.5}\right)$, making up approximately half of total $\mathrm{PM}_{2.5}$ mass (Querol et al., 2004; Pinder and Adams, 2007; Tsimpidi and Karydis, 2007; Yang et al., 2011). SNA aerosols have adverse effects on human health, visibility degradation, and global climate change (Hillamo et al., 1998; Adams and Seinfeld, 1999; Watson, 2002; Park et al., 2004, 2006; Pathak et al., 2009; Leibensperger et al., 2012a, b). Most of SNA aerosols are formed in the atmosphere through oxidation and neutralization of precursor gases: sulfur dioxide $\left(\mathrm{SO}_{2}\right)$, nitrogen oxides $\left(\mathrm{NO}_{\mathrm{x}}=\mathrm{NO}+\right.$ $\mathrm{NO}_{2}$ ), and ammonia $\left(\mathrm{NH}_{3}\right)$. The dominant pathway of sulfate formation is that $\mathrm{SO}_{2}$ is converted to sulfurous acid $\left(\mathrm{H}_{2} \mathrm{SO}_{3}\right)$ in the liquid phase $\left(\mathrm{SO}_{2}+\mathrm{H}_{2} \mathrm{O} \rightarrow \mathrm{H}_{2} \mathrm{SO}_{3}\right)$, followed by oxidation to sulfuric acid $\left(\mathrm{H}_{2} \mathrm{SO}_{4}\right)$ by hydrogen peroxide $\left(\mathrm{H}_{2} \mathrm{O}_{2}\right)$ and ozone $\left(\mathrm{O}_{3}\right)$, or by the catalytic oxidation of catalytic metals (Khoder, 2002). Monn and Schaeppi (1993) suggested that $\mathrm{SO}_{2}$ can be converted directly to $\mathrm{H}_{2} \mathrm{SO}_{4}$ through the reaction with hydroxyl radicals $(\mathrm{OH})$ or $\mathrm{H}_{2} \mathrm{O}_{2}$. The rate of $\mathrm{H}_{2} \mathrm{SO}_{4}$ formation through the liquid phase pathway will increase with increasing relative humidity and 
$\mathrm{OH}$ concentrations. A small part of $\mathrm{SO}_{2}$ is oxidized by $\mathrm{OH}$ to sulfur trioxide $\left(\mathrm{SO}_{3}\right)$ and then $\mathrm{H}_{2} \mathrm{SO}_{4}$ in the gas phase. Nitric acid $\left(\mathrm{HNO}_{3}\right)$ is formed through $\mathrm{NO}_{2}$ oxidized by $\mathrm{OH}$ during the daytime and hydrolysis of $\mathrm{N}_{2} \mathrm{O}_{5}$ at night. It is believed that the former is the dominant approach of $\mathrm{HNO}_{3}$ formation (Alexander et al., 2009). $\mathrm{H}_{2} \mathrm{SO}_{4}$ and $\mathrm{HNO}_{3}$ are neutralized mainly by $\mathrm{NH}_{3}$. $\left(\mathrm{NH}_{4}\right)_{2} \mathrm{SO}_{4}$ is the preferential species due to its stability. $\mathrm{NH}_{4} \mathrm{NO}_{3}$ is formed if excess $\mathrm{NH}_{3}$ is available beyond the sulfate requirement. $\mathrm{NH}_{4} \mathrm{NO}_{3}$ is volatile and its formation is more significant in winter (Meng and Seinfeld, 1994; Ansari and Pandis, 1998; Seinfeld and Pandis, 1998; Adams and Seinfeld, 1999). SNA aerosols are water-soluble and subject to wet and dry deposition.

The concentrations and compositions of SNA aerosols are determined primarily by their precursor emissions, which are mainly of anthropogenic origin. While $\mathrm{SO}_{2}$ and $\mathrm{NO}_{\mathrm{x}}$ emissions in the North Atlantic basin have been stabilized or are in decline, Asian emissions are still increasing (Benkovitz et al., 1996; Cofala et al., 2007; Smith et al., 2001, 2011). Emissions of $\mathrm{SO}_{2}$ and $\mathrm{NO}_{\mathrm{x}}$ in China increased dramatically by more than $60 \%$ and $80 \%$, respectively, from 2000 to 2006 (Zhang et al., 2009; Lu et al., 2011). $\mathrm{NO}_{\mathrm{x}}$ emissions in China were estimated to have maintained a mean annual growth rate of $6.7 \%$ from 2006 to 2009 (Lamsal et al., 2011). Chinese $\mathrm{SO}_{2}$ emissions were reported to have decreased by $9.2 \%$ from 2006 to 2010 (Lu et al., 2011), driven primarily by wide implementation of flue gas desulfurization in power plants. Agriculture is the largest contributor to $\mathrm{NH}_{3}$ emissions. Bouwman et al. (1997) estimated that the global $\mathrm{NH}_{3}$ emissions for 1990 were about $54 \mathrm{Tg} \mathrm{N} \mathrm{yr}^{-1}$ - about half of which were from Asia, with China accounting for the largest portion (Bouwman et al., 1997; Streets et al., 2003). In the 12th Five-Year Plan (FYP) (2011-2015), China set the emission reduction targets for $\mathrm{SO}_{2}$ and $\mathrm{NO}_{\mathrm{x}}$ of $8 \%$ and $10 \%$, respectively, for 2015, compared to 2010 levels (http://www. gov.cn/zwgk/2011-09/07/content_1941731.htm). In light of the significant impact of SNA aerosols on public health and climate, it is important to understand the extent of SNA concentration changes in response to past and future changes of $\mathrm{SO}_{2}, \mathrm{NO}_{\mathrm{x}}$ and $\mathrm{NH}_{3}$ emissions in China and to evaluate the effectiveness of currently available emission control policies.

Previous studies have explored the response of SNA to precursor emission changes (Pinder and Adams, 2007; Tsimpidi and Karydis, 2007, 2008). They found that composite SNA levels did not respond linearly to $\mathrm{SO}_{2}$ or $\mathrm{NO}_{\mathrm{x}}$ emission changes, with $\mathrm{NH}_{3}$ playing an important role in determining total SNA concentrations. Most of the previous studies have focused on the US, where precursor emissions of SNA have been effectively controlled and $\mathrm{PM}_{2.5}$ has been successfully incorporated into the National Ambient Air Quality Standards (NAAQS) and extensively monitored. China, despite facing serious $\mathrm{PM}_{2.5}$ pollution problems, has not drawn up the corresponding control standard or monitoring network for SNA or $\mathrm{PM}_{2.5}$. As a result, it is difficult to generate observation-based spatial distribution and temporal trend of
SNA across China to guide the precursor control policies. It would require a credible chemical transport model, evaluated by scattered in situ aerosol sampling in China, or satellitederived proxies such as aerosol optical depth (AOD), to simulate the SNA distributions, associate their concentrations with precursor emissions, and predict the concentration changes in response to future emission changes.

Previous studies have demonstrated the great potential of using satellite-retrieved AODs to derive the distribution of ground-level $\mathrm{PM}_{2.5}$ in conjunction with chemical transport models which provide the quantitative relationship from column-based AODs to surface $\mathrm{PM}_{2.5}$ masses (van Donkelaar et al., 2006, 2010). As SNA is a major component of surface $\mathrm{PM}_{2.5}$ mass, satellite-retrieved AODs can potentially be used to evaluate the distribution of surface SNA simulated by the model. An important step in this approach is to validate the satellite-retrieved AODs with ground-based optical depth measurements, as the satellite retrievals are known to be affected by surface reflectivity and cloud. On the other hand, one needs to evaluate also the ability of the model in simulating the vertical profiles of aerosols and their optical properties by chemical composition. Ground-based AOD measurements suitable to validate the satellite retrievals as well as in situ measurements of the vertical distribution of aerosols are also scarce in China.

In this study, we used a nested-grid version of a global chemical transport model (GEOS-Chem) to conduct fullyear simulations of SNA over China. Model results are evaluated with a few surface observations in and around China. We chose not to involve satellite-derived AODs for model evaluation considering the complexity discussed above. Our purpose is to understand the main factors determining the seasonal and spatial distributions of SNA over China, investigate the influence of precursor emission changes on SNA concentration changes from 2000 to 2015 , and provide policy suggestions for controlling SNA levels in China. The GEOSChem model and observation data used in this work are described in Sect. 2. The simulation results are evaluated with observations in Sect. 3. In Sect. 4, we will analyze the spatial and temporal distribution of SNA and their relationships to precursor emissions. The concentration changes of SNA in response to the 2000-2015 emission changes are discussed in Sect. 5. The concluding remarks are presented in Sect. 6.

\section{Model and observation}

\subsection{Model and simulations}

GEOS-Chem is a global 3-D chemical transport model driven by assimilated meteorological observations from the Goddard Earth Observing System (GEOS) of the NASA Global Modeling Assimilation Office. In this study we use the nested-grid capability of the GEOS-Chem model version 8-02-01 over East Asia ( $11^{\circ} \mathrm{S}-55^{\circ} \mathrm{N}, 70-150^{\circ}$ E; Fig. 3) 
Table 1. Simulation description.

\begin{tabular}{llllll}
\hline $\begin{array}{l}\text { Simulation } \\
\text { name }\end{array}$ & $\begin{array}{l}\text { Emission } \\
\text { year }\end{array}$ & $\begin{array}{l}\mathrm{SO}_{2} \\
\text { emissions (Tg) }\end{array}$ & $\begin{array}{l}\mathrm{NO}_{\mathrm{x}} \\
\text { emissions (Tg) }\end{array}$ & $\begin{array}{l}\mathrm{NH}_{3} \\
\text { emissions (Tg) }\end{array}$ & $\begin{array}{l}\text { Year of } \\
\text { meteorology }\end{array}$ \\
\hline $2006 \mathrm{C}$ & 2006 & 31 & 20.8 & 13.5 & 2007 \\
$2006 \mathrm{M}$ & 2006 & 31 & 20.8 & 13.5 & 2008 \\
$2000 \mathrm{C}$ & 2000 & 19.3 & 11.4 & 13.5 & 2007 \\
$2015 \mathrm{C}$ & 2015 & 25.9 & 24.26 & 13.5 & 2007 \\
$2006 \mathrm{~A}$ & 2006 & 31 & 20.8 & 9.45 & 2007 \\
$2015 \mathrm{~A}$ & 2015 & 25.9 & 24.26 & 15.73 & 2007 \\
\hline
\end{tabular}

with a horizontal resolution of $0.5^{\circ}$ latitude $\times 0.667^{\circ}$ longitude, as developed initially by Wang et al. (2004) and extended to the GEOS-5 meteorology by Chen et al. (2009).

The SNA simulation coupled with gas-phase chemistry was developed originally by Park et al. (2004). The aerosol thermodynamic equilibrium in v8-02-01 uses the RPMARES model (Binkowski and Poselle, 2003) which calculates the gas-aerosol phase partitioning of a $\mathrm{H}_{2} \mathrm{SO}_{4}-\mathrm{HNO}_{3}-\mathrm{NH}_{3}-\mathrm{H}_{2} \mathrm{O}$ equilibrium system. $\mathrm{NH}_{3}$ prefers to form $\left(\mathrm{NH}_{4}\right)_{2} \mathrm{SO}_{4}$ due to its stability in the atmosphere. The formation of $\mathrm{NH}_{4} \mathrm{NO}_{3}$ is limited by the availability of $\mathrm{NH}_{3}$ and atmospheric conditions. The dissociation constant of $\mathrm{NH}_{4} \mathrm{NO}_{3}$ depends on temperature and relative humidity. $\mathrm{NH}_{4} \mathrm{NO}_{3}$ dissociates quickly in high temperature and low relative humidity conditions (Mozurkewich, 1993). The newer versions of GEOS-Chem adopt ISORROPIA II as the aerosol thermodynamic equilibrium module, which considers a more complex aerosol system including other ions such as $\mathrm{K}^{+}, \mathrm{Ca}^{2+}, \mathrm{Mg}^{2+}, \mathrm{Na}^{+}$and $\mathrm{Cl}^{-}$(Fountoukis and Nenes, 2007). We found that ISORROPIA II produces more nitrate than RPMARES does for China, resulting in larger model biases compared with observations (Sect. 3). Recent studies also found that the positive bias of nitrate simulation in GEOS-Chem was not corrected using ISORROPIA II (Heald et al., 2012; Pye et al., 2009). The wet deposition scheme, including rainout in cloud and washout below cloud, is described by Liu et al. (2001). Dry deposition is based on the resistance-in-series scheme of Wesely (1990) as implemented by Wang et al. (1998).

The GEIA (Global Emission Inventory Activity) inventory (Benkovitz et al., 1996) is the baseline anthropogenic inventory in the GEOS-Chem global model, and the global anthropogenic ammonia emissions are from Bouwman et al. (1997). Scale factors based on energy statistics and other information are used to obtain the emission inventory for the simulation year, as implemented by van Donkelaar et al. (2008) following on the work of Bey et al. (2001) and Park et al. (2004). The GEIA inventory is overwritten by the NEI05 inventory over the US and the EMEP inventory over Europe. For East Asia, anthropogenic emissions of $\mathrm{NO}_{\mathrm{x}}$ and $\mathrm{SO}_{2}$ are taken from the inventory of Zhang et al. (2009) for 2006, and $\mathrm{NH}_{3}$ emissions are taken from Streets et al. (2003) for 2000 .
We conducted five series of 15-month simulations with different emissions but the same meteorology from October 2006 to December 2007, with the first 3 months for initialization and the next 12 months for analysis. The simulations are summarized in Table 1. The emission scenarios were formulated on the basis of $\mathrm{SO}_{2}$ emissions that have long been the primary target of air pollution control policy in China since the 11th FYP. We choose year 2000 to represent the past condition when $\mathrm{SO}_{2}$ emissions were lowest since 1996 (Lu et al., 2011), 2006 to represent the present case when $\mathrm{SO}_{2}$ emissions peaked, and 2015 to represent the future scenario, assuming a successful implementation of the 12th FYP to control $\mathrm{SO}_{2}$. In the 2000 case simulation (2000C), anthropogenic emissions, including $\mathrm{SO}_{2}, \mathrm{NO}_{\mathrm{x}}$ and $\mathrm{NH}_{3}$, were taken from the 2000 emissions inventory by Streets et al. (2003) for East Asia. In the 2006 case simulation (2006C), we adopted the 2006 anthropogenic emissions inventory for East Asia by Zhang et al. (2009), including $\mathrm{NO}_{\mathrm{x}}$ and $\mathrm{SO}_{2}$ but not $\mathrm{NH}_{3}$. The 2015 case simulation $(2015 \mathrm{C})$ uses the same emissions inventory as $2006 \mathrm{C}$ but scales the national total of $\mathrm{SO}_{2}$ and $\mathrm{NO}_{\mathrm{x}}$ emissions from their 2006 levels by factors determined as follows: compared to 2006 levels, the national total emissions in 2010 are $9.2 \%$ lower for $\mathrm{SO}_{2}$ (Lu et al., 2011) and $29.6 \%$ higher for $\mathrm{NO}_{\mathrm{x}}$ (Lamsal et al., 2009). According to the 12 th FYP, reductions of $8 \%$ and $10 \%$ were applied to $\mathrm{SO}_{2}$ and $\mathrm{NO}_{\mathrm{x}}$, respectively, from their emission levels in 2010 to obtain emissions in 2015 . The emissions inventory of $\mathrm{NH}_{3}$ in 2000 from Streets et al. (2003) is used in both $2006 \mathrm{C}$ and $2015 \mathrm{C}$. As the emissions estimate for $\mathrm{NH}_{3}$ is more uncertain than $\mathrm{SO}_{2}$ and $\mathrm{NO}_{\mathrm{x}}$ (Dong et al., 2010; Huang et al., 2011, 2012; Kim et al., 2006; Streets et al., 2003; Zhang et al., 2010), we set up two more cases - 2006A and 2015A - to investigate the sensitivity of SNA to various $\mathrm{NH}_{3}$ emissions. Ammonia emissions in 2006A and 2015A are 30\% lower and $16.7 \%$ higher than those in $2006 \mathrm{C}$ and $2015 \mathrm{C}$, respectively. A more detailed discussion of $\mathrm{NH}_{3}$ emissions will be given in Sect. 3. Monthly variation in emissions was adopted from Zhang et al. (2007) for $\mathrm{NO}_{\mathrm{x}}$, Lu et al. (2011) for $\mathrm{SO}_{2}$, and Fisher et al. (2011) for $\mathrm{NH}_{3}$. To examine the sensitivity of model results to the meteorological year, we conducted another full-year simulation using the same emissions as in $2006 \mathrm{C}$ but driven by the 2008 meteorology (referred to 
(a) $\mathrm{SO}_{2}$

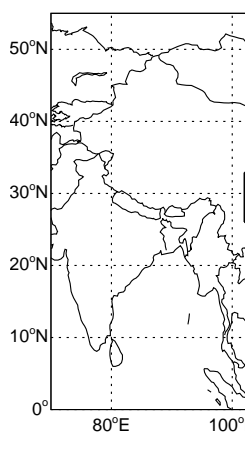

(b) $\mathrm{NO}_{\mathrm{x}}$

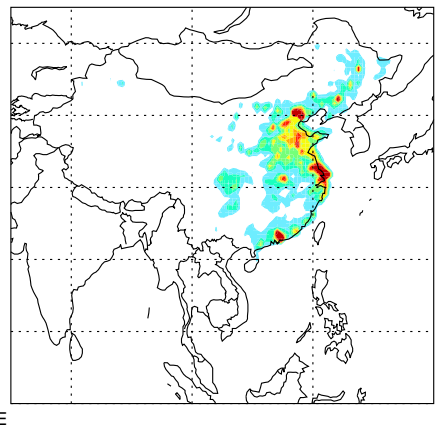

(c) $\mathrm{NH}_{3}$

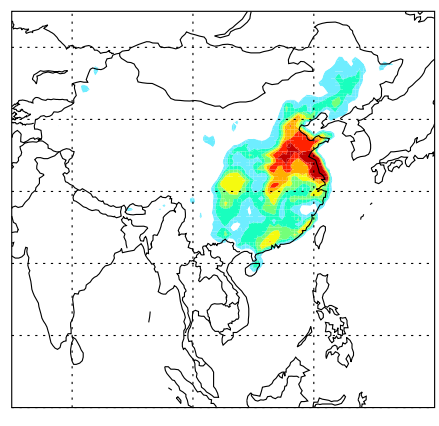

$\times 10^{12}$ atmos $\mathrm{S} / \mathrm{N} \mathrm{cm}^{2} \mathrm{~s}$

Fig. 1. Spatial distributions of (a) $\mathrm{SO}_{2}$, (b) $\mathrm{NO}_{\mathrm{x}}$ and (c) $\mathrm{NH}_{3}$ emissions from China used in the 2006C simulation. Please note that this figure is not the whole East Asian model domain, which is shown in Fig. 3, and that emissions outside of China are omitted. The rectangles in (a) represent North China (upper right), South China (lower right), and the Sichuan Basin (left).
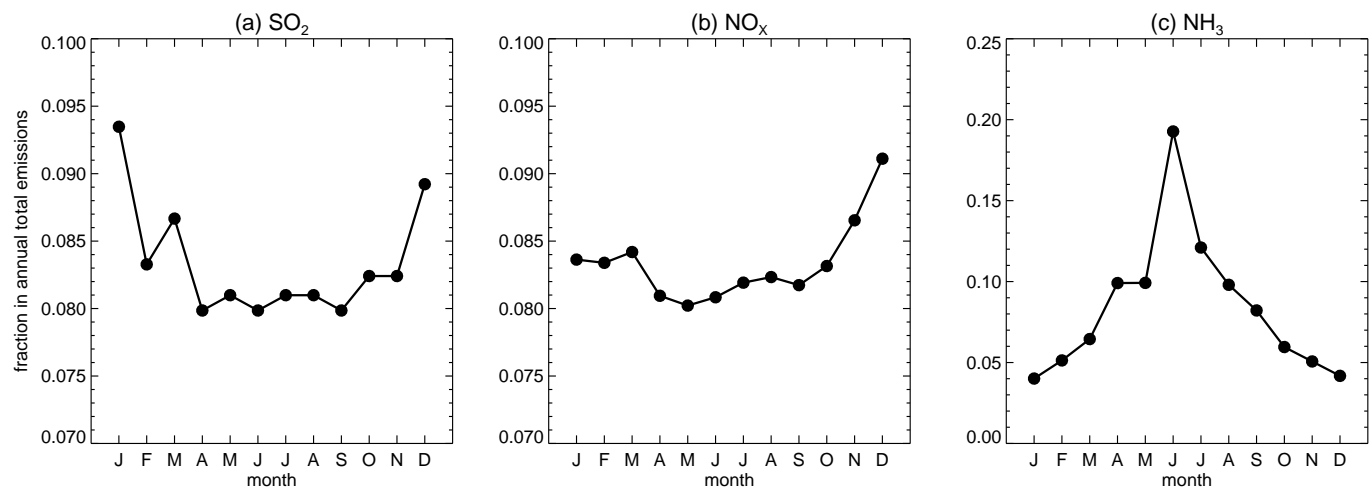

Fig. 2. Seasonality of (a) $\mathrm{SO}_{2}$, (b) $\mathrm{NO}_{\mathrm{x}}$ and (c) $\mathrm{NH}_{3}$ emissions from China.

2006M case in Table 1). The monthly variability of emissions is the same for all the simulations.

The spatial distributions of $\mathrm{SO}_{2}, \mathrm{NO}_{\mathrm{x}}$ and $\mathrm{NH}_{3}$ emissions over China in 2006C are presented in Fig. 1. High emissions of the three species were concentrated mainly over three regions: North China $\left(\mathrm{NC}, 32-42^{\circ} \mathrm{N}, 110-120^{\circ} \mathrm{E}\right.$ ), South China $\left(\mathrm{SC}, 22-32^{\circ} \mathrm{N}, 110-120^{\circ} \mathrm{E}\right)$, and the Sichuan Basin (SCB, $\left.27-33^{\circ} \mathrm{N}, 102-110^{\circ} \mathrm{E}\right)$. Total emissions from the three regions accounted for more than $2 / 3$ of total $\mathrm{SO}_{2}$, $\mathrm{NO}_{\mathrm{x}}$ and $\mathrm{NH}_{3}$ emissions in China. Among the three regions, emission intensity was highest in NC. The emission intensity of $\mathrm{SO}_{2}$ was also large in SCB. On the molecular basis, $\mathrm{NH}_{3}$ emissions were less than the sum of $\mathrm{SO}_{2}$ and $\mathrm{NO}_{\mathrm{x}}$ emissions, indicating $\mathrm{NH}_{3}$-limited conditions through China in 2006. Figure 2 shows the seasonal variation of the emissions. Emissions of $\mathrm{SO}_{2}$ and $\mathrm{NO}_{\mathrm{x}}$ were highest in DJF (DecemberFebruary) and lowest in JJA (June-August), whereas $\mathrm{NH}_{3}$ emissions were highest in JJA and lowest in DJF. The former pattern was driven by heating demand and industry, and the latter was caused by agriculture practice and temperature.
The seasonal variation was much larger for $\mathrm{NH}_{3}$ than for $\mathrm{SO}_{2}$ or $\mathrm{NO}_{\mathrm{x}}$.

\subsection{Observations}

There is no in situ measurement network of aerosols in China that is publicly accessible (Chan and Yao, 2008). We had access to weekly mean observations of SNA concentrations at two rural sites in China: the Miyun (MY, 40 $29^{\prime} \mathrm{N}$, $116^{\circ} 47^{\prime} \mathrm{E}$ ) site in Beijing and the Beibei $\left(\mathrm{BB}, 29^{\circ} 50^{\prime} \mathrm{N}\right.$, $106^{\circ} 25^{\prime} \mathrm{E}$ ) site in Chongqing. MY is located at the northern edge of the North China Plain, about $100 \mathrm{~km}$ northeast from Beijing's urban center. There are no distinct anthropogenic pollution sources within a $1 \mathrm{~km}$ radius of the site. The sampling time was from January to December 2007. BB is located in the Sichuan Basin in Southwest China. It is $10 \mathrm{~km}$ from the Beibei city center (a small city with a population of 650000), and there are no distinct anthropogenic pollution sources within $2 \mathrm{~km}$ of the site. The sampling time was from February 2005 to April 2006. At both sites, the aerosol samples were taken with a low flow sampling instrument that collects $\mathrm{PM}_{2.5}$ every week. The chemical composition of 
$\mathrm{PM}_{2.5}$ was analyzed in the laboratory. Previous studies (Yang et al., 2011; He et al., 2012) based on SNA observations from these two sites have revealed the concentration levels and composition characteristics, and they indicated that $\mathrm{PM}_{2.5}$ compositions at the two sites can be regarded as representative of regional conditions in North and Southwest China.

We also collected annual mean SNA observations during the 2004-2008 period from published studies (Feng et al., 2007; Hagler et al., 2006; Yang et al., 2005, 2008; Wang et al., 2006; X. Y. Zhang et al., 2012). For model evaluation purposes, monthly mean observations of SNA concentrations in East Asia were obtained from the Acid Deposition Monitoring Network in East Asia (EANET, http://www.eanet.cc/). Wet deposition fluxes of SNA were also collected from EANET to evaluate the simulated SNA budget. Geographical locations of all the observational sites used in this study are shown in Fig. 3, which depicts the nested-grid East Asian model domain $\left(11^{\circ} \mathrm{S}-55^{\circ} \mathrm{N}, 70-150^{\circ} \mathrm{E}\right)$. Although many of the EANET sites are located outside of China, they lie within the East Asian model domain and thus provide useful observations to evaluate the model.

The filter-based sampling method of SNA can cause measurement artifacts. Positive biases of sulfate may result from absorption of $\mathrm{SO}_{2}$ into the ammonium-rich sulfate particles collected on the filter during sampling, so the filter material should not absorb acid and alkali gases. Teflon filters are preferred in this regard. Negative biases of nitrate and ammonium generally occur due to volatilization of $\mathrm{NH}_{4} \mathrm{NO}_{3}$, especially in dry regions (Pathak et al., 2009). At the MY and BB sites, aerosols are sampled with the low-volume sampler produced by American Aerosol Dynamics. To reduce the negative bias of $\mathrm{NH}_{4} \mathrm{NO}_{3}$ sampling, a nylon filter is positioned downstream of the Teflon filter to capture the $\mathrm{NH}_{3}$ and $\mathrm{HNO}_{3}$ that volatize from the Teflon filter (Zhao et al., 2010). The filter pack method is used for aerosol collection for the EANET sites, and they also use the Teflon filters to collect SNA aerosols.

\section{Model evaluation}

The GEOS-Chem simulation of SNA has been evaluated with extensive surface observations in the US (Park et al., 2004, 2006; Pye et al., 2009; Leibensperger et al., 2012a; L. Zhang et al., 2012) and with aircraft measurements of East Asian outflow in springtime (Park et al., 2004; Heald et al., 2005). The model was found capable of reproducing the spatial and seasonal patterns of total SNA and its components. The model generally had small biases in simulating sulfate concentrations and deposition, but tended to overestimate nitrate at the surface. Our model evaluation with observations will focus on the spatial and seasonal distribution of total SNA (TSNA) and all three components (sulfate, nitrate and ammonium) at the surface over China and East Asia, using simulation results from $2006 \mathrm{C}$.

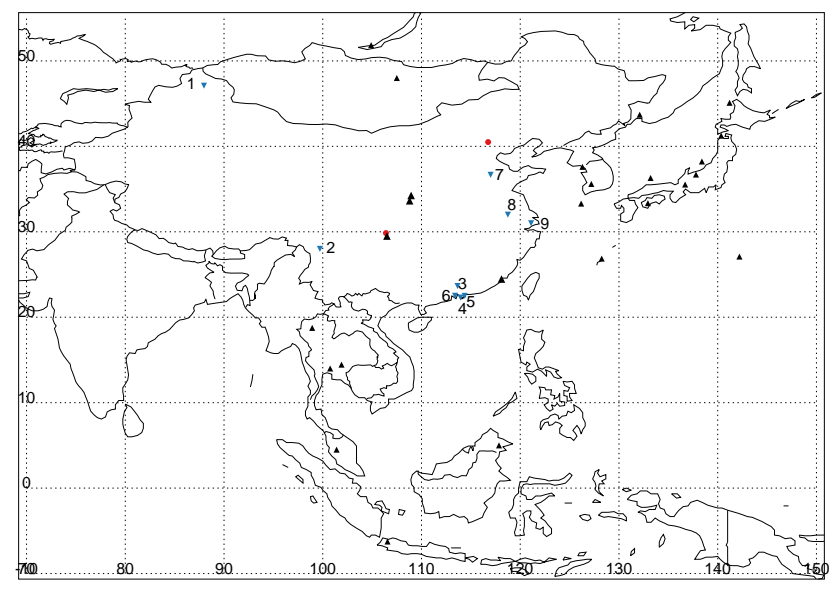

Fig. 3. The nested-grid model domain and locations of observational data used in this study. The black triangles represent 25 sites from EANET; the red circles represent Miyun and Beibei sites with weekly observations; blue inverted triangles represent 9 Chinese rural sites from published papers: (1) Akdala, (2) Shangrl-La (X. Y. Zhang et al., 2012), (3) Conghua, (4) Tung Chung, (5) Tap Yun, (6) Zhongshan (Hagler et al., 2006), (7) Jinan (Yang, 2008), (8) Nanjing (Yang et al., 2005), and (9) Shanghai (Wang et al., 2006).

Figure 4 presents simulated annual mean distribution of sulfate, nitrate, ammonium, and TSNA at the surface over China, overlaid with surface observations at a few sites. The model has excellent ability in reproducing the observed spatial heterogeneity of TSNA and all three components across China, with high concentrations over $\mathrm{NC}$ for all species, over SCB for sulfate and ammonium, and over SC for sulfate. SNA concentrations are lowest in the west, where annual mean TSNA is less than $10 \mu \mathrm{g} \mathrm{m}^{-3}$. The model has relatively small biases in simulating sulfate, ammonia and TSNA across China, but overestimates nitrate in East China. As indicated before, nitrate overestimation is a common problem found in previous GEOS-Chem studies (Park et al., 2004; Leibensperger et al., 2012a; L. Zhang et al., 2012) as well as in other chemical transport models such as CMAQ (Kim et al., 2006) and PMCAMx (Fountoukis et al., 2011). The reasons are partly attributed to the difficulties in precisely measuring nitrate, as $\mathrm{NH}_{4} \mathrm{NO}_{3}$ may volatize on the Teflon filter and gaseous $\mathrm{NH}_{3}$ and $\mathrm{HNO}_{3}$ will escape, and partly to the model's treatment of deposition and uncertainties of ammonia emission inventory to be discussed below.

The scatter plot of simulated versus observed seasonal mean sulfate, nitrate, ammonium and TSNA concentrations at 22 sites in East Asia (20 from EANET, plus MY and BB) are displayed in Fig. 5, with the regression slopes and squares of correlation coefficients $\left(R^{2}\right)$ given in insert. The model represents a good performance on sulfate simulation with a relatively high $R^{2}(0.64-0.79$ by season $)$ and small biases, ranging from $-18 \%$ (MAM; March-May) to $7 \%$ (SON; September-November). The annual mean model bias 
(a) sulfate

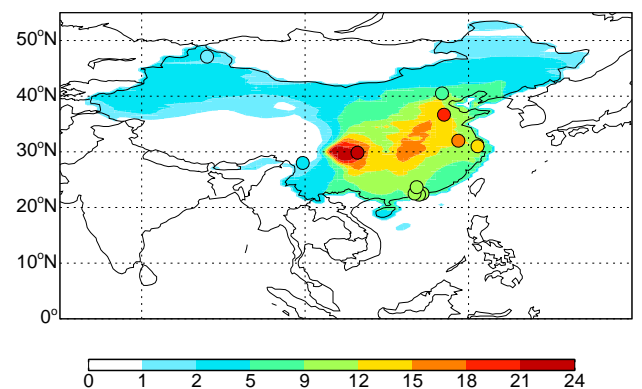

(c) ammonium

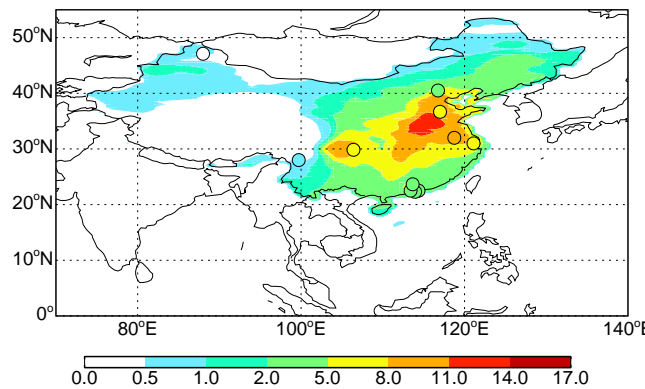

(b) nitrate
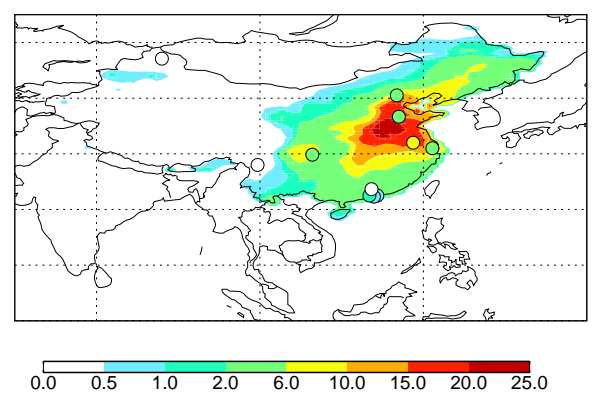

(d) TSNA

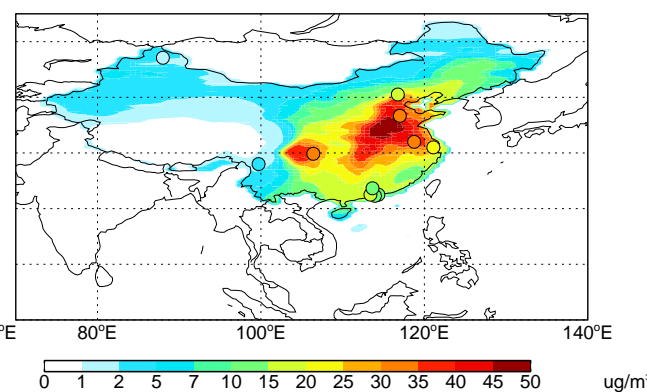

Fig. 4. Overlay of simulated (color map) and observed (colored circles) annual mean surface concentrations of total SNA (TSNA), sulfate, nitrate and ammonium over China. Observations are derived from the MY and BB sites with weekly measurements and from the 9 sites in published literature (i.e., the blue triangle sites shown in Fig. 3).

of sulfate was $-10 \%$. The model had large positive biases (+31\% annually) and poorer correlation for nitrate, with the annual mean $R^{2}$ of 0.42 and seasonal mean $R^{2}$ ranging from 0.22 (MAM) to 0.69 (JJA). For ammonium, the model had an annual mean bias of $35 \%$ and the largest overestimation occurred in JJA (43\%). Despite the bias, the model reproduced the variability of ammonium observations well $\left(R^{2}=0.73\right.$ annually and $0.57-0.83$ by season). For the composite TSNA, the model successfully captured the spatial variability $\left(R^{2}=0.58-0.78\right)$ and concentration levels of observations with an annual mean bias of $6 \%$. This is because the underestimation of sulfate and overestimation of nitrate cancel out in TSNA. As sulfate is the largest component of TSNA in China, the better simulation of sulfate dominates in the comparison for TSNA.

The weekly averages of simulated and observed concentrations of SNA at the MY and BB sites are displayed in Fig. 6. At MY, sulfate peaked in JJA, while nitrate and ammonium exhibited double peaks in JJA and DJF. Simulated sulfate levels at MY corresponded well with observations in terms of both variability and concentrations with a correlation coefficient $(R)$ close to 0.7 and a mean bias of $+15 \%$. The model has a weaker ability in capturing the sawtooth-like variation of sulfate in summer, especially the very low sulfate concentrations, which may be attributed to the model's discrepancy in simulating large precipitation and high wind speeds on a local scale at MY (Wang et al., 2012). The model captured the variability of observed nitrate and ammonium at
MY, but overestimated their concentrations throughout the year by an average of $150 \%$ and $65 \%$, respectively. The model's bias for nitrate was largest in JJA. At BB, sulfate, nitrate and ammonium all showed a winter maximum and summer minimum. Although the model reproduced the seasonal variability of observations at $\mathrm{BB}$, it shows a weaker ability in reproducing the week to week variations of SNA than at MY. This is because the observations at BB are for 2005 while the model uses 2006 meteorology. The mean model biases at $\mathrm{BB}$ are $-16 \%,+62 \%$ and $+20 \%$ for sulfate, nitrate and ammonium, respectively.

Wet deposition is the main removal pathway of SNA aerosols from the atmosphere. To evaluate the model's ability of simulating wet deposition, we compared the simulated and observed wet deposition fluxes of SNA at 25 EANET sites (Fig. 7), including 5 Chinese sites and 20 sites in other East Asian countries around China. We found that the model had relatively poor ability in capturing the observed variation of SNA wet deposition $\left(R^{2}=0.18-0.4\right)$. The model underestimated wet deposition of sulfate and nitrate by more than $40 \%$, but the model bias for ammonium wet deposition was not significant. The model's underestimation of nitrate deposition may be one explanation for the model's large overestimation of nitrate concentrations. We conducted a sensitivity simulation in which the rate constant of nitrate wet deposition was increased by $40 \%$. Compared with the standard simulation, the sensitivity simulation had $20 \%$ higher nitrate wet deposition fluxes and $7 \%$ higher nitrate concentrations 


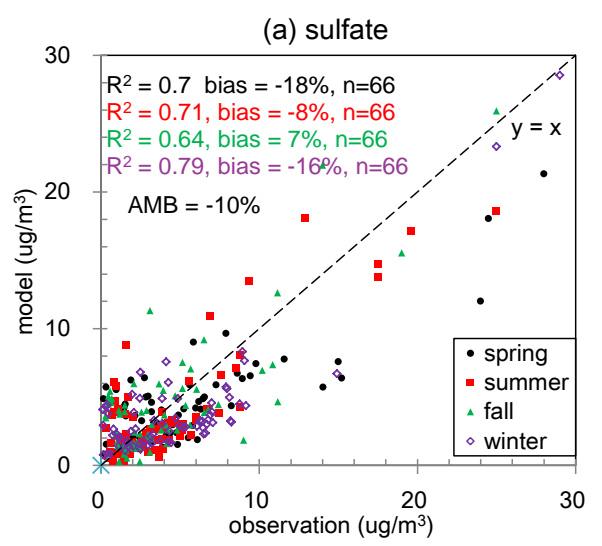

(c) ammonium

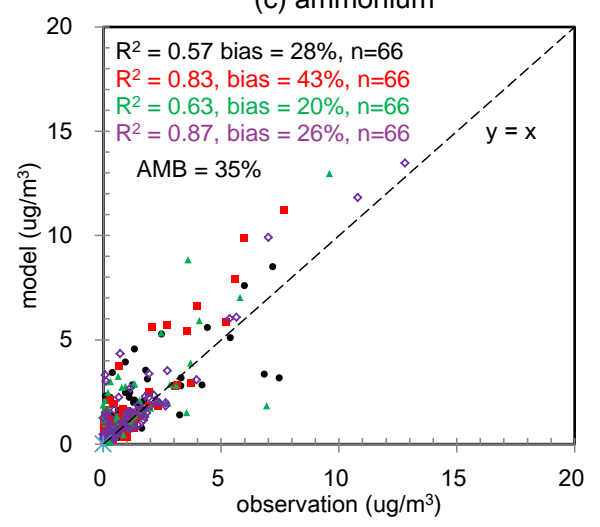

(b) nitrate

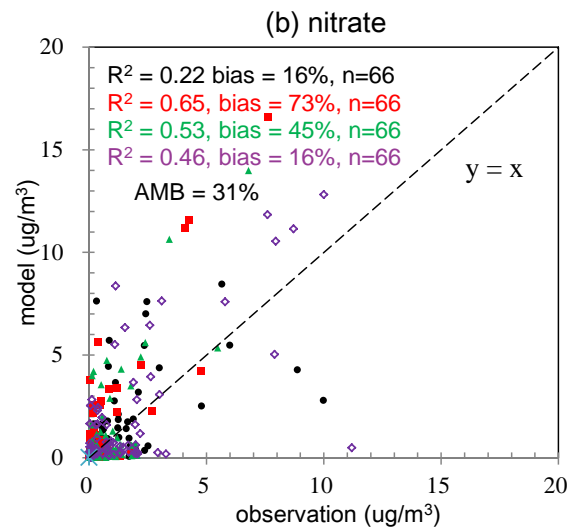

(d) TSNA

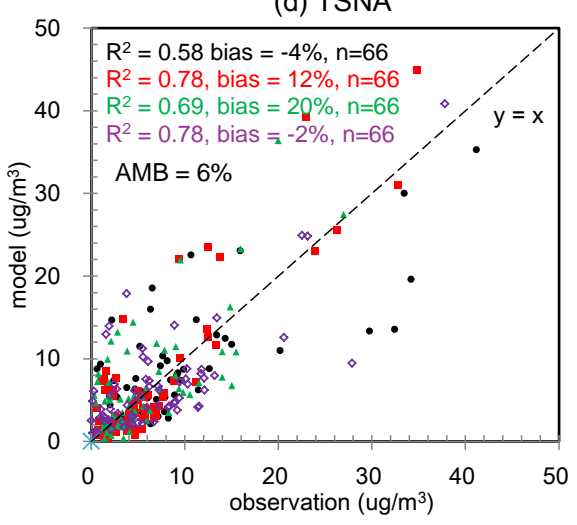

Fig. 5. Scatter plots of simulated versus observed SNA concentrations at 22 (the 4 EANET sites inside China have no observation data for SNA) sites in East Asia, including 2 sites in China (BB and MY) and 20 sites from other countries. Values are seasonal mean for 2006 . The black dots represent spring, the red squares represent summer, the green triangles represent fall, and the violet hollow diamonds represent winter. $\mathrm{AMB}=$ annual mean bias. The square of correlation coefficient $\left(R^{2}\right)$, normalized mean bias, and annual mean bias $(\mathrm{AMB})$ are given in each scatter plot. The $y=x$ relationship (dashed lines) is shown.

at the surface, matching better with observations. The discrepancies in the wet deposition rates may be caused by the inability of the model to reproduce large precipitation events at local scales given its relatively coarse resolution (Wang et al., 2012).

The model overestimated ammonium surface concentrations, indicating that there may be an overestimation of ammonia emissions in the model. Overestimation of $\mathrm{NH}_{3}$ favors partitioning of nitrate in the aerosol phase, as ammonium nitrate's formation requires free $\mathrm{NH}_{3}$ that has not reacted with sulfuric acid. Estimates of $\mathrm{NH}_{3}$ emissions in China vary greatly among published papers (Streets et al., 2003; Kim et al., 2006; Dong et al., 2010; Zhang et al., 2010; Huang et al., 2011, 2012), suggesting that $\mathrm{NH}_{3}$ emissions inventories are subject to large uncertainties in China. The most recent estimate of $\mathrm{NH}_{3}$ emissions in China by Huang et al. (2012) is $9.8 \mathrm{Tg}$ for year 2006 , which is much lower than that of 13.5 Tg for 2000 from Streets et al. (2003) and 16.07 Tg for 2006 from Dong et al. (2010). Kim et al. (2006) suggested that the ACE-ASIA NH 3 emissions (Streets et al., 2003) used in their model should be reduced by $20-75 \%$ in order to ad- just for the overestimation of nitrate over East Asia. To evaluate the sensitivity of nitrate simulation to $\mathrm{NH}_{3}$ emissions in the model, we set up the $2006 \mathrm{~A}$ case, in which $\mathrm{NH}_{3}$ emissions were reduced by $30 \%$ compared to 2006C. Simulated nitrate and TSNA concentrations were reduced by more than $30 \%$ and $10 \%$ in 2006A, respectively, compared to 2006C, matching better with observations. Simulated nitrate concentrations are thus more sensitive to $\mathrm{NH}_{3}$ emissions than to wet deposition parameters discussed above. As expected, there was little change in sulfate concentrations. This suggests that the overestimation of $\mathrm{NH}_{3}$ emissions in China might be the primary reason for nitrate overestimation in the model, although more direct evaluation of the $\mathrm{NH}_{3}$ inventory used in the model is definitely needed before one can draw a conclusion on the possible high bias of the $\mathrm{NH}_{3}$ inventory. Given the scarcity of in situ $\mathrm{NH}_{3}$ measurements, column densities of $\mathrm{NH}_{3}$ retrieved for example by the TES (Shephard et al., 2011) and IASI (Clarisse et al., 2009) satellite instruments have been applied by a few pioneering studies to evaluate the bottom-up $\mathrm{NH}_{3}$ inventories (e.g., Heald et al., 2012). Shephard et al. (2011) indicated that the GEOS-Chem simulated 

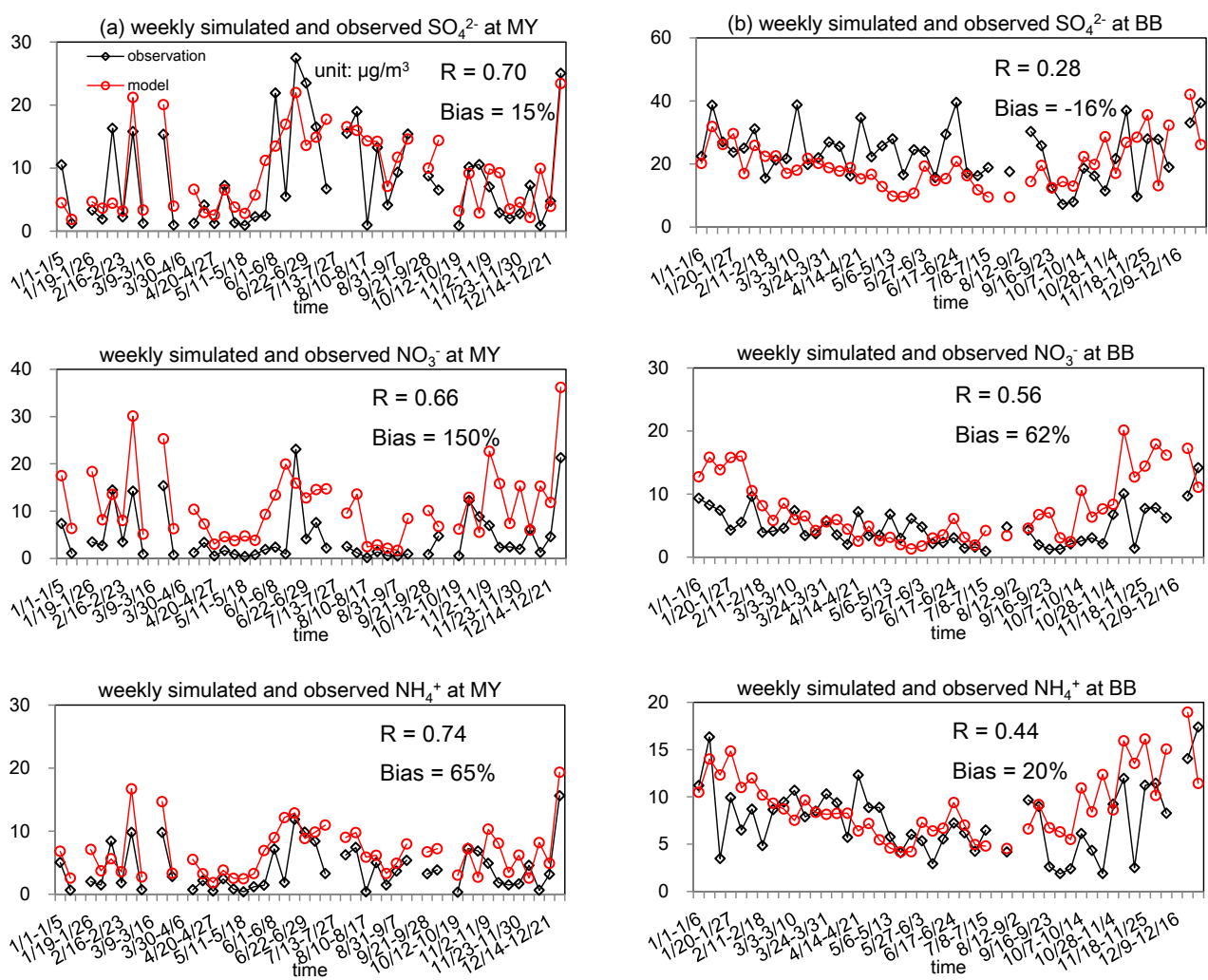

Fig. 6. The weekly averages of simulated and observed mass concentrations of sulfate, nitrate and ammonium (top to down) at the MY (a) and BB (b) sites. The black lines represent observations and the red lines represent the simulation. The correlation coefficient and model bias are given.
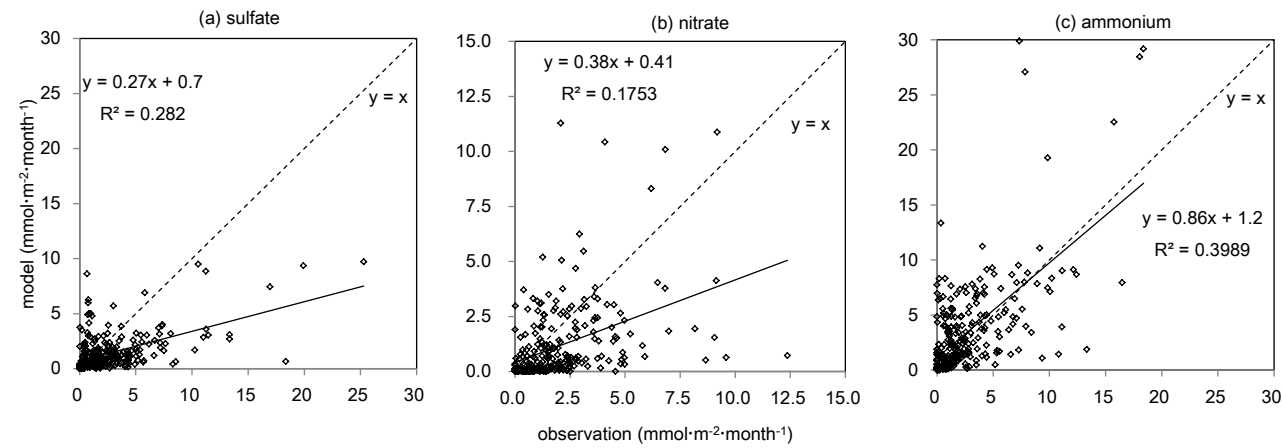

Fig. 7. Scatter plots of simulated (y-axis) versus observed (x-axis) SNA wet deposition fluxes. The square of correlation coefficient $\left(R^{2}\right)$ and the normalized mean bias are given.

$\mathrm{NH}_{3}$ columns were lower than those retrieved from TES over East Asia, whereas Kharol et al. (2013) found that the GEOSChem model with $30 \%$ lower $\mathrm{NH}_{3}$ emissions over China can reproduce the $\mathrm{NH}_{3}$ columns retrieved from IASI. Considering the model biases in nitrate and ammonium, the uncertainty in $\mathrm{NH}_{3}$ emissions, and the fact that the emission inventory of $\mathrm{NH}_{3}$ by Streets et al. (2003) for year 2000 was already $38 \%$ too high compared to the latest estimate by Huang et al. (2012) for the year 2006, we chose to use the $\mathrm{NH}_{3}$ inventory for year 2000 from Streets et al. (2003) in 2006C and 2015C, without applying additional increasing factors by year.

Figure 8 shows the observed and simulated (2006C, 2006A, and 2006M) annual mean SNA compositions at the MY and BB sites, where we had weekly continuous observations. As discussed before, MY can be regarded as representative of NC, and BB as representative of SCB. Observed annual mean sulfate concentrations were $190 \%$ higher at BB than at MY, which largely contributed to the overall higher TSNA levels at BB than MY. Nitrate concentrations were 
(a) composition of TSNA at MY

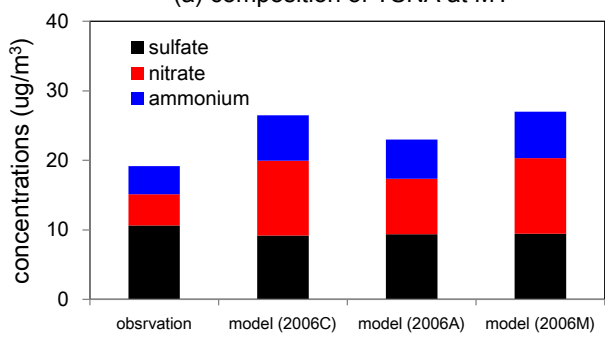

(b) composition of TSNA at BB

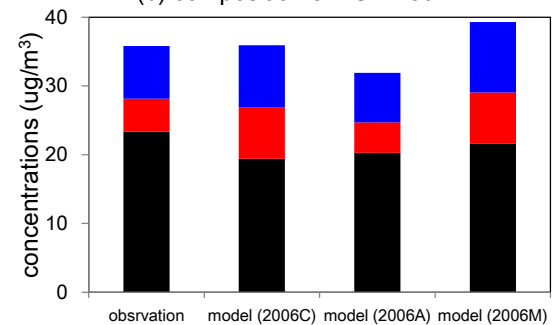

Fig. 8. Observed and simulated annual mean SNA composition and concentrations at the MY (a) and BB (b) sites. Model results from 2006C, 2006A and 2006M simulations are displayed.

$10 \%$ higher at BB than at MY. The fractional contribution of sulfate and nitrate to TSNA was $50 \%$ and $26 \%$ at MY, respectively, compared to that of $66 \%$ and $14 \%$ at BB. The model (both 2006C and 2006A) successfully captured the concentration gradient of TSNA and its components between MY and BB. The 2006C case overestimated the absolute concentrations of nitrate and ammonium and their fractional shares in TSNA at both sites. The overestimation was especially serious for nitrate at MY. In the 2006A case with reduced $\mathrm{NH}_{3}$ emissions, the model results were much closer to observations, indicating again that overestimation of nitrate can be largely corrected by reducing the ammonia emissions in China used as model input. The difference in simulated SNA concentrations between the $2006 \mathrm{C}$ and $2006 \mathrm{M}$ cases, which differ only in meteorology, is within $2 \%$ for all SNA species at MY. At the BB site, although simulated sulfate and ammonium concentrations in $2006 \mathrm{M}$ are about $10 \%$ higher than those in $2006 \mathrm{C}$, the relative contribution of individual species to TSNA shows little change from 2006C to 2006M. The comparison between $2006 \mathrm{C}$ and $2006 \mathrm{M}$ at the two sites suggests the overall small sensitivity of the model results to the meteorological year.

In summary, the model has some success in simulating the spatial and seasonal distribution of TSNA and its components over China, and has small biases in reproducing surface concentrations of sulfate and TSNA. The overestimation of nitrate could be largely corrected by reducing $\mathrm{NH}_{3}$ emissions in China used as model input. Given the lack of sufficient information on the past and present levels of $\mathrm{NH}_{3}$ emissions in China, more direct evaluation of the $\mathrm{NH}_{3}$ inventory used in the model is definitely needed. Given the model's ability, the following analysis will mainly focus on the changes of TSNA and sulfate in response to precursor emission changes from 2000 to 2015. We will also examine the changes in nitrate and ammonium from 2000 to 2015 , but more in the relative sense, and will involve the $\mathrm{NH}_{3}$ sensitivity cases (2006A and 2015A).

\section{Spatial and seasonal patterns of SNA across China}

Since the model has some success in capturing the spatial distributions and seasonal patterns of SNA aerosols, we used the model to examine the key factors determining the spatial and seasonal variations of SNA aerosols over China in the present-day case (2006C). As the response of SNA formation to precursor emissions is expected to differ by region and by season due to different meteorology and emissions characteristics, this analysis forms the basis of understanding the past and future changes of SNA presented in Sect. 5.

Figure 9 shows the seasonal mean concentrations of TSNA, sulfate, nitrate and ammonium across China. Sulfate is the largest component in total SNA all over China. All SNA species are highest in DJF, followed by SON, and lowest in MAM or JJA. This seasonal pattern was in accordance with that of $\mathrm{SO}_{2}$ and $\mathrm{NO}_{\mathrm{x}}$ emissions. Higher concentrations were distributed over NC, SC and SCB in all seasons, coinciding with the spatial pattern of highest precursor emissions. Sulfate concentrations were highest in SCB, while nitrate, ammonium, and TSNA were highest in NC.

Figure 10 compares the mean seasonal variations of sulfate, nitrate, ammonium and TSNA averaged over NC, SC and SCB from the 2006C and 2006A cases. As sulfate concentrations showed little sensitivity to the $30 \%$ reduction of $\mathrm{NH}_{3}$ emissions in 2006A, the 2006A simulation for sulfate is not shown. Sulfate showed a JJA maximum and MAM minimum in NC, whereas an opposite seasonal pattern was found in SC and SCB with a JJA minimum and DJF maximum. The annual mean concentration of sulfate is more or less the same between NC and SC, and it is highest over SCB, reaching about $14 \mu \mathrm{g} \mathrm{m}^{-3}$. Sulfate made up about $40 \%$ of total SNA mass over NC, and the ratio was highest in JJA (45\%) and lowest in DJF (30\%). By contrast, sulfate contributed $50 \%$ and $60 \%$ to total SNA mass in SC and SCB, respectively, and its fraction in TSNA changed little with seasons in both regions. Both gas- and aqueous-phase oxidation of $\mathrm{SO}_{2}$ were expected to peak in JJA because of higher temperature, more abundant sunlight, and higher humidity (Yao et al., 2002; Ye et al., 2002; Wang et al., 2006; X. Y. Zhang et al., 2012). The seasonal pattern of sulfate over NC corresponds with that of 

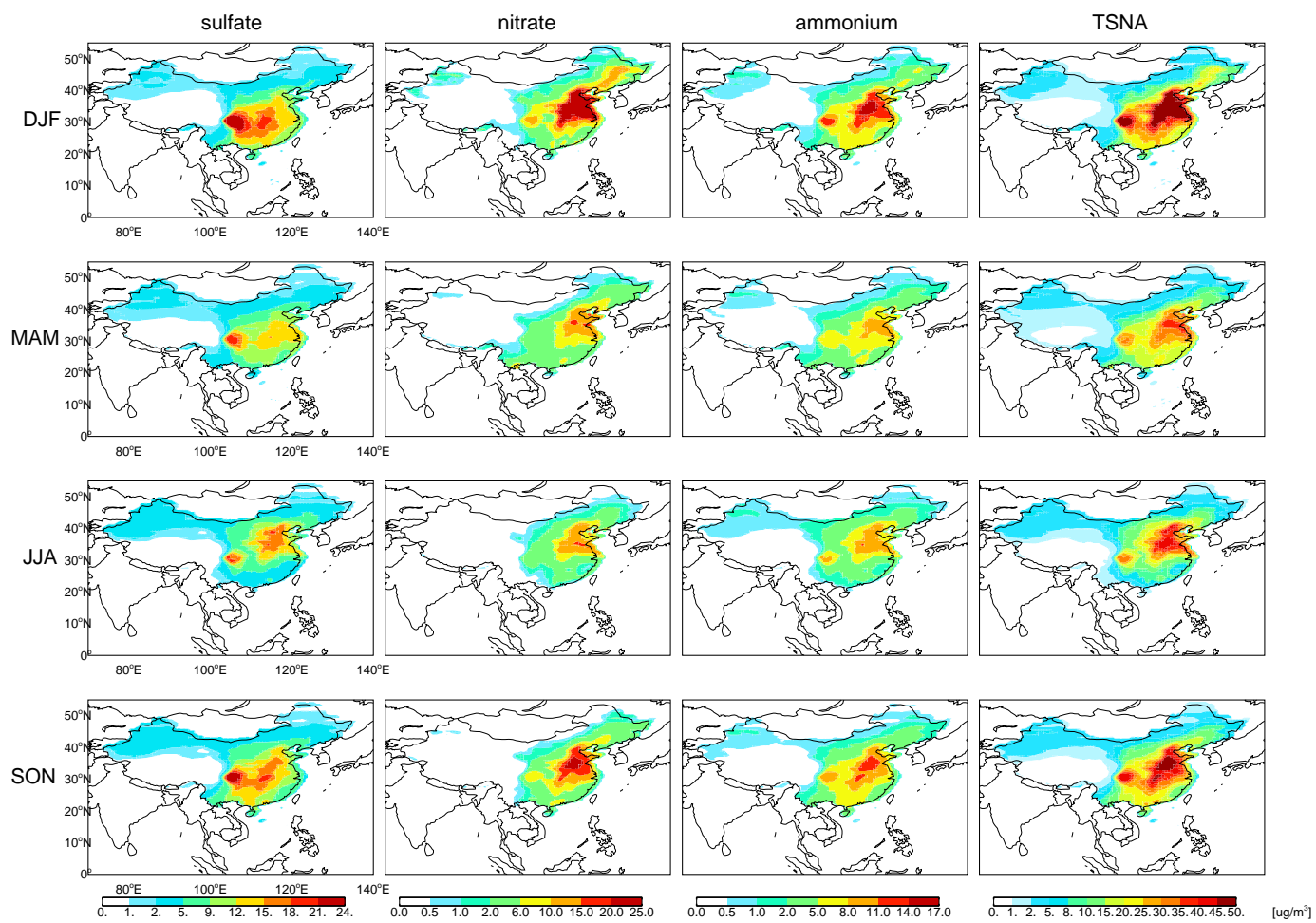

Fig. 9. Simulated seasonal mean surface concentrations of sulfate, nitrate, ammonium and TSNA (left to right) in December-February (DJF), March-May (MAM), June-August (JJA) and September-November (SON) 2006.

(a) seasonal variation of sulfate

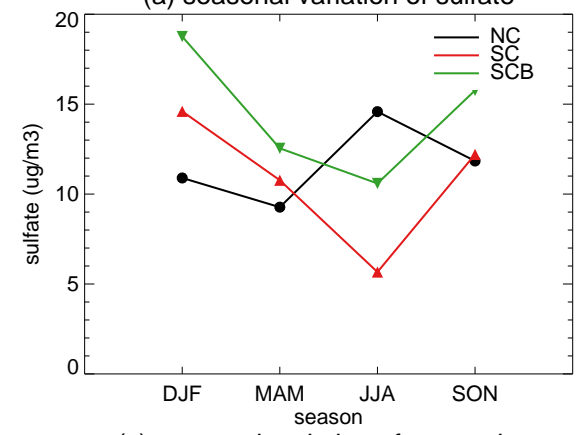

(c) seasonal variation of ammonium

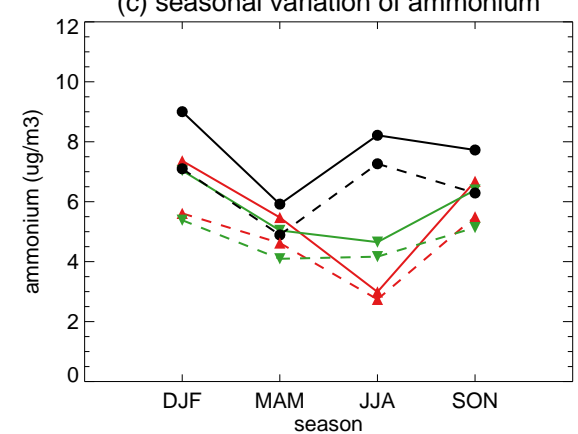

(b) seasonal variation of nitrate

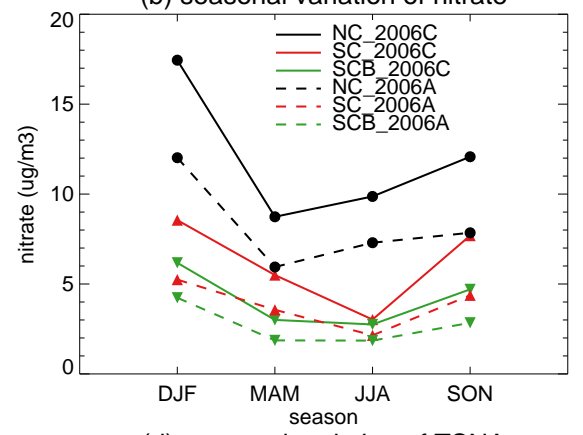

(d) seasonal variation of TSNA

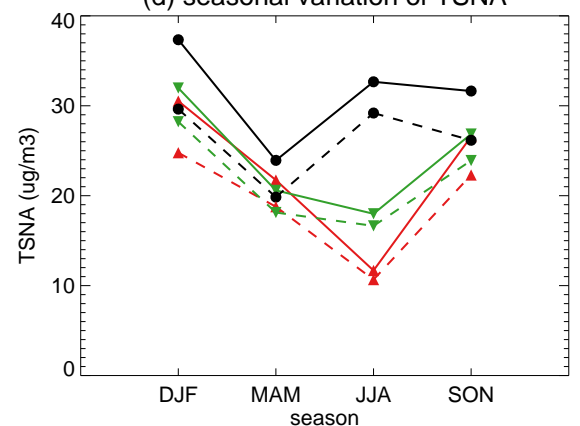

Fig. 10. Simulated seasonal mean concentrations of (a) sulfate, (b) nitrate, (c) ammonium and (d) TSNA over NC, SC and SCB. The black lines represent NC, red lines represent SC and green lines represent SCB. The solid lines represent 2006C results and dashed lines represent 2006A results. 
oxidation, suggesting that the limiting factor determining the seasonality of sulfate over $\mathrm{NC}$ is the chemical formation rate of sulfate rather than $\mathrm{SO}_{2}$ emissions or wet deposition, both of which favor a JJA minimum in sulfate. This is also supported by the fact that annual mean sulfate concentrations are similar between $\mathrm{NC}$ and $\mathrm{SC}$, despite much higher emissions of $\mathrm{SO}_{2}$ over the former, particularly in winter. Over $\mathrm{SC}$ and $\mathrm{SCB}$, the seasonal variation of meteorological factors determining the formation rate of sulfate (i.e., temperature, relative humidity, and solar radiation) is not as pronounced as in NC because of lower latitude. As a result, the seasonality of sulfate over these regions (a DJF maximum and JJA minimum) is driven more by that of $\mathrm{SO}_{2}$ emissions and wet deposition.

Nitrate shows a DJF maximum over the three regions, which can be explained in part by higher $\mathrm{NO}_{\mathrm{x}}$ emissions in winter. As atmospheric $\mathrm{NH}_{4} \mathrm{NO}_{3}$ formation is constrained strongly by temperature (Wang et al., 2006), the low temperature in winter is favorable for $\mathrm{NH}_{4} \mathrm{NO}_{3}$ formation. Nitrate is lowest in spring over NC and in summer over SC and SCB. Among the three regions, nitrate concentrations are highest over $\mathrm{NC}$ throughout the year, as both $\mathrm{NO}_{\mathrm{x}}$ and $\mathrm{NH}_{3}$ emissions are highest over this region. Ammonium and TSNA have two peaks over NC, one in winter due to highest nitrate concentrations and one in summer due to highest sulfate concentrations. Over SC and SCB, they are highest in DJF and lowest in JJA, similar to the seasonality of sulfate and nitrate. All SNA species are lowest in spring over NC due to higher wind speeds in this season which favor dispersion and export of SNA to the southern regions. Over SC and SCB, all SNA species are lowest in summer as precipitation, and hence wet scavenging, peak in summer.

In the present-day case (2006), sulfate is the dominant component of SNA over SC and SCB, while nitrate and sulfate contribute equally over NC. We have shown that chemical oxidation rate is the dominant factor in determining SNA concentration levels and seasonality over NC, whereas the key factors are emissions and wet deposition over SC and SCB. Given the regional differences presented above, it is expected that future SNA concentrations over SC and SCB may be more sensitive to $\mathrm{SO}_{2}$ emission changes, while those over $\mathrm{NC}$ may show more complex responses to precursor emissions.

\section{SNA variations from 2000 to 2015 due to precursor emission changes}

From 2000 to 2006, $\mathrm{SO}_{2}$ and $\mathrm{NO}_{\mathrm{x}}$ emissions in China increased by more than $60 \%$ and $80 \%$, respectively. Since 2006, China has moved aggressively to reduce $\mathrm{SO}_{2}$ emissions. In the 11th FYP (2006-2010), China set a goal to reduce $10 \%$ of $\mathrm{SO}_{2}$ emissions in order to control acid rain and PM pollution. It is suggested that this goal was realized and Chinese $\mathrm{SO}_{2}$ emissions decreased by $9.2 \%$ from 2006 to 2010 (Lu et al., 2011). Zhao et al. $(2008,2011)$ suggested that the benefits of reducing soil acidification from $\mathrm{SO}_{2}$ emission control may be negated by increases of $\mathrm{NO}_{\mathrm{x}}$ and $\mathrm{NH}_{3}$ emissions. $\mathrm{NO}_{\mathrm{x}}$ emission reductions were proposed later in the 12th FYP (2011-2015). As elaborated before, we calculated that $\mathrm{SO}_{2}$ emissions in 2015 will be lower by $16 \%$ and $\mathrm{NO}_{\mathrm{x}}$ emissions higher by $16 \%$ compared to the corresponding 2006 levels. Given the large uncertainty in current estimates of $\mathrm{NH}_{3}$ emissions, we first examined the changes in atmospheric SNA concentrations over China driven by $\mathrm{SO}_{2}$ and $\mathrm{NO}_{\mathrm{x}}$ emission changes from 2000 to 2015 . We then discuss the sensitivity of the future SNA changes to changing $\mathrm{NH}_{3}$ emissions.

\subsection{SNA changes from 2000 to 2015}

Figure 11 shows the relative increase of $\mathrm{SO}_{2}$ and $\mathrm{NO}_{\mathrm{x}}$ emissions from 2000 to 2006 over China. There was significant spatial heterogeneity in the emission change patterns. Total $\mathrm{SO}_{2}$ emissions over NC, SC, and SCB in 2006 were $44 \%$, $87 \%$, and $130 \%$ higher compared with their levels in 2000 . Driven by the rapid growth of the motor vehicle population, $\mathrm{NO}_{\mathrm{x}}$ emissions increased at a faster rate than $\mathrm{SO}_{2}$ emissions. Total $\mathrm{NO}_{\mathrm{x}}$ emissions over the three regions in 2006 were more than twice of those in 2000, with SCB experiencing the largest relative increase $(140 \%)$. The emission changes over Northwest and Northeast China, although large in the relative term, were much smaller in magnitude compared with those in other regions. In the $2015 \mathrm{C}$ simulation, under the assumption of a successful realization of $\mathrm{SO}_{2}$ and $\mathrm{NO}_{\mathrm{x}}$ emission reduction targets during the 12th $\mathrm{FYP}$, total $\mathrm{SO}_{2}$ and $\mathrm{NO}_{\mathrm{x}}$ emissions in China are $16 \%$ lower and $16 \%$ higher than those in $2006 \mathrm{C}$, respectively. The spatial distribution of $\mathrm{NO}_{\mathrm{x}}$ and $\mathrm{SO}_{2}$ emissions in China is the same between $2006 \mathrm{C}$ and $2015 \mathrm{C}$ and $\mathrm{NH}_{3}$ emissions are kept constant.

Figure 12 shows the absolute difference in simulated annual mean mass concentrations of sulfate, nitrate, and TSNA between different emission scenarios: 2006C minus 2000C (12a) and 2015C minus 2006C (12b). The concentration change from 2000 to 2006 (2006C minus 2000C; Fig. 12a) was positive over all regions of China, with significant increases distributed in the east, particularly over $\mathrm{NC}, \mathrm{SC}$ and SCB. The sulfate increase was largest in SCB, by more than $6 \mu \mathrm{g} \mathrm{m}^{-3}$, compared with that of $4 \mu \mathrm{g} \mathrm{m}^{-3}$ in NC and SC. The relative increase of sulfate in NC, SC and SCB were $49 \%, 64 \%$ and $86 \%$ from 2000 to 2006, corresponding almost linearly to the relative increase of $\mathrm{SO}_{2}$ emissions in these regions. The nitrate increase was largest in NC, by about $4 \mu \mathrm{g} \mathrm{m}^{-3}$, compared with that of $1-2 \mu \mathrm{g} \mathrm{m}^{-3}$ in SC and $\mathrm{SCB}$. The relative increase of nitrate, ranging from $40 \%$ to $60 \%$ in the three regions, was much less than the relative increase of $\mathrm{NO}_{\mathrm{x}}$ emissions. As $\mathrm{NH}_{3}$ emissions were held constant from 2000 to 2006 in the simulations, given the large simultaneous increase in $\mathrm{SO}_{2}$ emissions, there was no excess $\mathrm{NH}_{3}$ available to form nitrate despite the large increase 
(a) $\mathrm{SO}_{2}$ emission ratio between 2006 and 2000

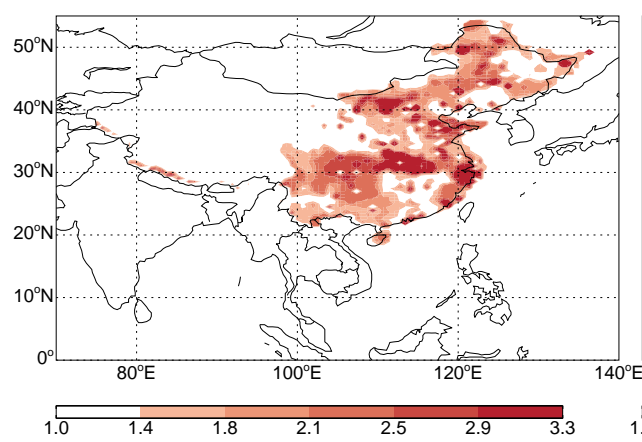

(b) $\mathrm{NO}_{\mathrm{x}}$ emission ratio between 2006 and 2000

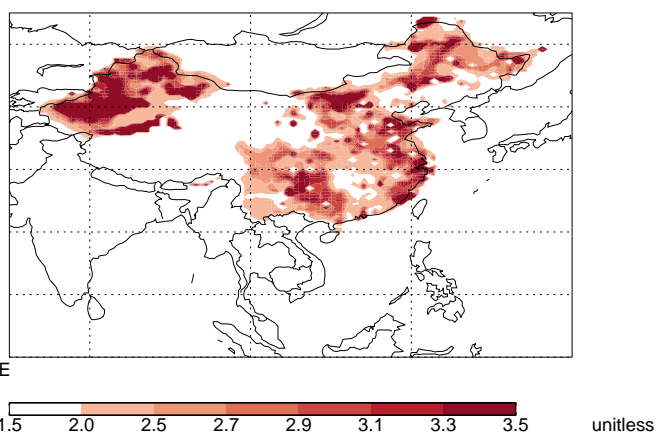

Fig. 11. (a) $\mathrm{SO}_{2}$ and (b) $\mathrm{NO}_{\mathrm{x}}$ emission changes from 2000 to 2006 in China. The data shown are the ratios of 2006 emissions to 2000 emissions.

(a) sulfate (2006C-2000C)

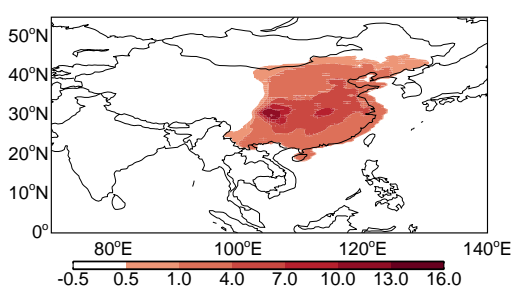

(b) sulfate (2015C-2006C)

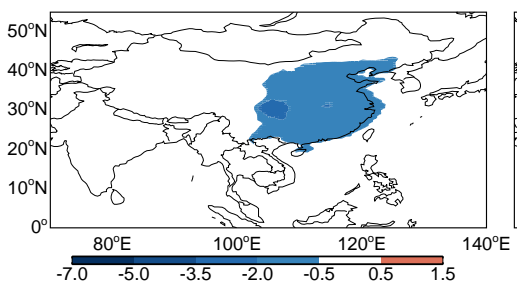

(c) sulfate (2015A-2006C)

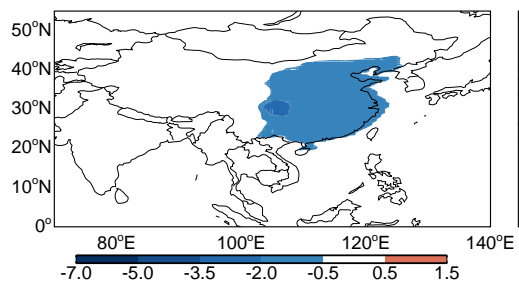

nitrate (2006C-2000C)

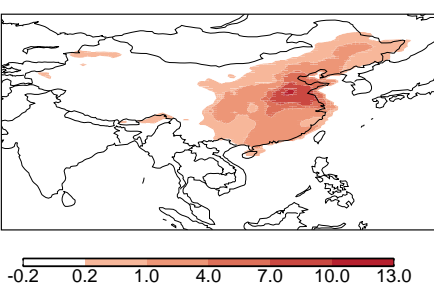

nitrate (2015C-2006C)

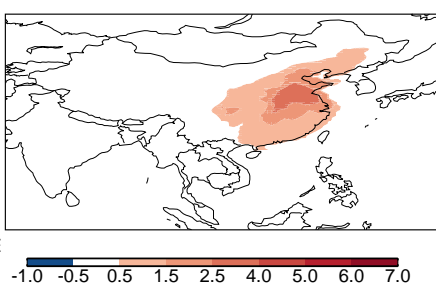

nitrate (2015A-2006C)

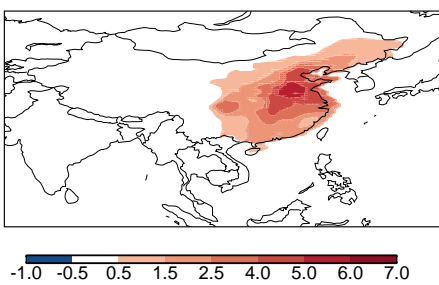

TSNA (2006C-2000C)

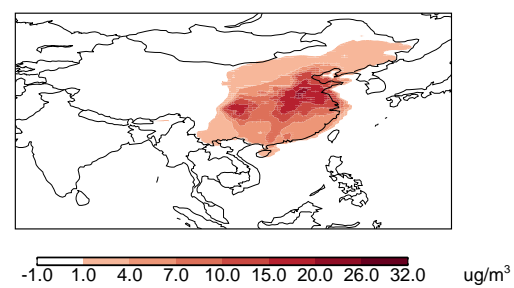

TSNA (2015C-2006C)

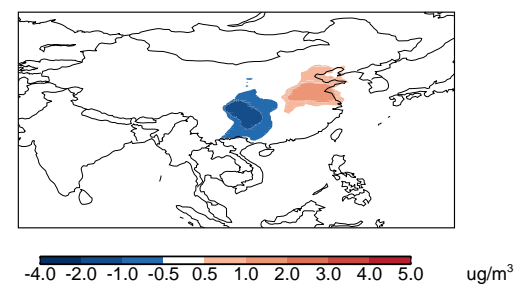

TSNA (2015A-2006C)

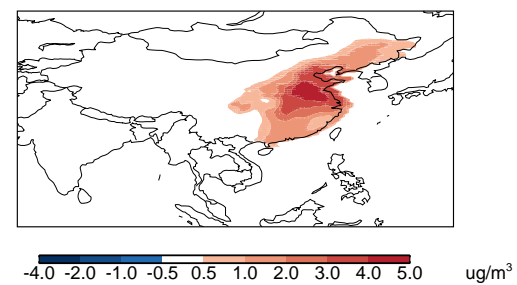

Fig. 12. The changes in mass concentrations of sulfate (left), nitrate (middle), and TSNA (right) from 2000 to 2015 . (a) The changes from 2000C to 2006C; (b) the changes from 2006C to 2015C; and (c) the changes from 2006C to 2015A. Note that the color scale in (a) is different from that in (b) or (c).

of $\mathrm{NO}_{\mathrm{x}}$ emissions. TSNA concentrations increased by about $10 \mu \mathrm{g} \mathrm{m}^{-3}$ over the three regions, and the relative change was $54-68 \%$ due to the increase of sulfate and nitrate concentrations. Figure $12 \mathrm{~b}$ shows the absolute difference (2015C minus 2006C) in annual mean mass concentrations of sulfate, nitrate, and TSNA due to $\mathrm{SO}_{2}$ and $\mathrm{NO}_{\mathrm{x}}$ emission changes from 2006 to 2015 over all regions of China. Sulfate decreases all over China, and the largest decrease of sulfate occurs in SCB, reaching up to $7 \mu \mathrm{g} \mathrm{m}^{-3}$. The average reduction of sulfate over NC, SC, and SCB is $-2 \mu \mathrm{g} \mathrm{m}^{-3}$ or $-14 \%$, corresponding almost linearly to the $-16 \%$ decrease of national total $\mathrm{SO}_{2}$ emissions from $2006 \mathrm{C}$ to $2015 \mathrm{C}$. There is no obvious difference in the relative change of sulfate concentrations between the three regions. By contrast, nitrate shows an increase all over China. The largest absolute increase of nitrate mass concentrations is found over $\mathrm{NC}$, reaching up to $+2 \mu \mathrm{g} \mathrm{m}^{-3}$ annually. The relative increase of nitrate is much higher over SC and SCB, reaching $23 \%$. The average mass 

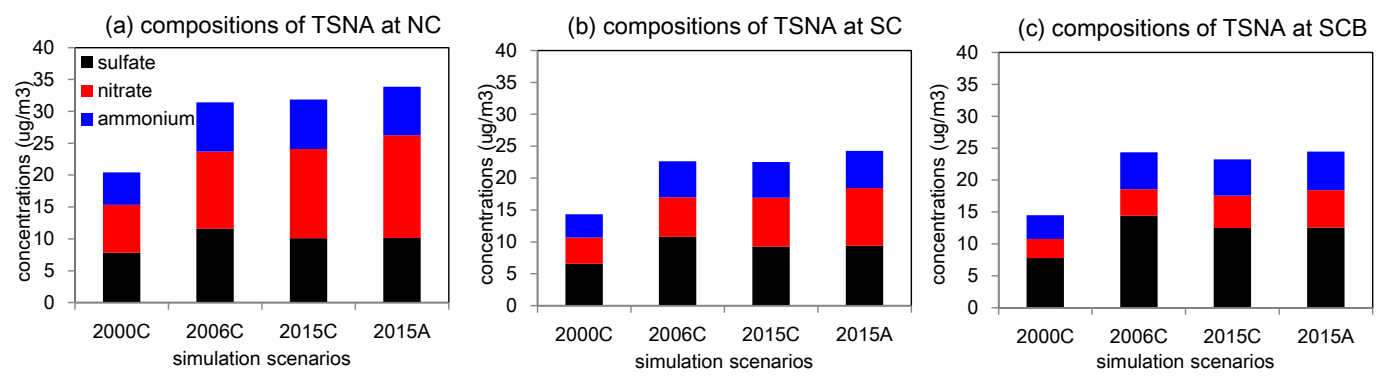

Fig. 13. Simulated composition and concentration changes of SNA aerosols from 2000 to 2015 over (a) NC, (b) SC and (c) SCB. Four simulation cases are compared: 2000C, 2006C, 2015C, and 2015A.

concentration of nitrate increases by $20 \%$ over China, larger than the $+16 \%$ relative increase of national total $\mathrm{NO}_{\mathrm{x}}$ emissions between the two cases. As discussed in Sect. 2, China was in $\mathrm{NH}_{3}$-limited conditions in 2006, meaning that there was not enough free $\mathrm{NH}_{3}$ to neutralize all the nitric acid in the atmosphere. The decrease of sulfate in 2015 releases free $\mathrm{NH}_{3}$ by a $1: 2$ ratio, as one molecule of $\left(\mathrm{NH}_{4}\right)_{2} \mathrm{SO}_{4}$ reduction releases two molecules of free $\mathrm{NH}_{3}$. Since the formation of $\mathrm{NH}_{4} \mathrm{NO}_{3}$ requires a $1: 1$ ratio between nitric acid and $\mathrm{NH}_{3}$, the amount of $\mathrm{NH}_{3}$ released from sulfate reduction can make additional nitrate after neutralizing all the additional nitric acid resulting from the $16 \%$ increase of $\mathrm{NO}_{\mathrm{x}}$ emissions. This explains why the fractional increase of nitrate $(+20 \%)$ is larger than the fractional increase of national total $\mathrm{NO}_{\mathrm{x}}$ emissions $(+16 \%)$ between the two cases. TSNA is found to either decrease or increase depending on the region. Over NC, TSNA mass concentrations increase by $2 \%$, suggesting that the increase of $\mathrm{NO}_{\mathrm{x}}$ emissions outplays the decrease of $\mathrm{SO}_{2}$ emissions in determining the sign of SNA concentration change. In SCB, TSNA mass concentrations decrease by $5 \%$, indicating that the effect of $\mathrm{SO}_{2}$ emission decrease on SNA is larger than that of $\mathrm{NO}_{\mathrm{x}}$ emission increase. Over SC, TSNA mass concentrations change little from 2006 to 2015, indicating that the effect of $\mathrm{NO}_{\mathrm{x}}$ emission increase balances that of $\mathrm{SO}_{2}$ emission decrease. Note that the relative change of $\mathrm{SO}_{2}$ and $\mathrm{NO}_{\mathrm{x}}$ emissions from 2006 to 2015 is the same in magnitude although opposite in sign $\left(-16 \%\right.$ for $\mathrm{SO}_{2}$ and $+16 \%$ for $\mathrm{NO}_{\mathrm{x}}$ ), and such changes are applied uniformly over China without spatial or seasonal differences. Therefore, the different regional change of TSNA in terms of sign and magnitude indicates not only the strong nonlinearity of SNA to precursor emission changes, but also the dependence of such nonlinearity on regional precursor emission mix and composition of SNA.

\subsection{SNA changes by region}

The annual mean SNA mass concentrations and speciation simulated in different emission scenarios are summarized by region in Fig. 13. Over NC, nitrate and sulfate made up approximately equal contributions to total mass concentrations of SNA in $2000 \mathrm{C}$ and $2006 \mathrm{C}$, and their relative proportions in SNA did not change between the two cases despite increases in their absolute concentrations. This suggests that both $\mathrm{SO}_{2}$ and $\mathrm{NO}_{\mathrm{x}}$ emission changes contributed to increasing SNA concentrations from $2000 \mathrm{C}$ to $2006 \mathrm{C}$ over NC. Over SC and $\mathrm{SCB}$, however, sulfate was the largest contributor to SNA, making up $45 \%$ and $53 \%$ of mean SNA masses over the two regions in $2000 \mathrm{C}$, respectively. The fractional contribution of sulfate to total SNA increased to $50 \%$ over SC and $60 \%$ over SCB in 2006C, whereas the relative contribution of nitrate to total SNA showed a noticeable decrease from 2000C to 2006C. Over SCB, for example, the fraction of nitrate in TSNA decreased from $21 \%$ in $2000 \mathrm{C}$ to $17 \%$ in $2006 \mathrm{C}$, despite a $1.2 \mu \mathrm{g} \mathrm{m}^{-3}$ increase in nitrate mass concentrations. This suggests that the increase of $\mathrm{SO}_{2}$ emissions was the main driver of increasing TSNA concentrations over SC and SCB from $2000 \mathrm{C}$ to $2006 \mathrm{C}$, with $\mathrm{NO}_{\mathrm{x}}$ emission increases playing a secondary role. This is because the formation of $\left(\mathrm{NH}_{4}\right)_{2} \mathrm{SO}_{4}$ is preferential over that of $\mathrm{NH}_{4} \mathrm{NO}_{3}$ given a constant supply of $\mathrm{NH}_{3}$ emissions.

The chemical composition of SNA aerosols also changes from 2006 to 2015. There is a general increase in the proportion of nitrate in total SNA in 2015C compared with 2006C, especially over NC where nitrate's contribution to SNA surpasses that of sulfate and becomes the predominant component of SNA. Over SC and SCB, sulfate is still the largest contributor to total SNA; especially in SCB where sulfate's proportion is greater than $50 \%$, even in $2015 \mathrm{C}$. The change of concentration levels and speciation of SNA aerosols from $2006 \mathrm{C}$ to $2015 \mathrm{C}$ suggest that the $\mathrm{SO}_{2}$ emissions control target set forth by the 12th FYP is effective in reducing total SNA over SC and SCB, but not over NC, for which $\mathrm{NO}_{\mathrm{x}}$ emissions control should be strengthened. Furthermore, considering the highest TSNA concentrations, greater efforts should be taken for emissions abatement in this region.

The nonlinear response of SNA to precursor emissions change also differs by season. We summarize the relative change of SNA mass concentrations (2015C minus 2006C) over NC, SC, and SCB in winter (DJF) and summer (JJA) in Table 2. We find that the relative decrease of sulfate in winter is twice that in summer in all three regions despite the same 
Table 2. The percentage change of sulfate, nitrate and TSNA mass concentrations from 2006C to 2015C (2015C minus 2006C), averaged for summer (June, July, August; JJA) and winter (December, January, February, DJF).

\begin{tabular}{llrrr}
\hline & & Sulfate & Nitrate & TSNA \\
\hline NC & DJF & $-19 \%$ & $17 \%$ & $0.5 \%$ \\
& JJA & $-10 \%$ & $19 \%$ & $0.4 \%$ \\
\hline \multirow{2}{*}{ SC } & DJF & $-19 \%$ & $29 \%$ & $-2 \%$ \\
& JJA & $-11 \%$ & $21 \%$ & $0.2 \%$ \\
\hline \multirow{2}{*}{ SCB } & DJF & $-19 \%$ & $20 \%$ & $-7 \%$ \\
& JJA & $-10 \%$ & $20 \%$ & $-4.5 \%$ \\
\hline
\end{tabular}

fractional reduction of $\mathrm{SO}_{2}$ emissions applied in both seasons. As the mass concentration of sulfate peaks in winter except over NC (cf., Fig. 10), this suggests that $\mathrm{SO}_{2}$ emissions control is more effective in reducing sulfate levels in winter. The relative change of nitrate mass concentrations is nearly the same in DJF and JJA. Given that mass concentrations of nitrate in winter are typically twice that of those in summer (cf., Fig. 10), $\mathrm{NO}_{\mathrm{x}}$ emissions control should be stressed in winter. Over $\mathrm{NC}$, in which we show above that the increase of $\mathrm{NO}_{\mathrm{x}}$ emissions outplays the decrease of $\mathrm{SO}_{2}$ emissions in determining annual mean TSNA concentrations, the fractional change of TSNA concentrations is small in magnitude (0.4$0.5 \%$ ) and similar between winter and summer. By contrast, TSNA decreases over SC and SCB and the relative decrease is much higher in winter than in summer.

\subsection{Sensitivity of SNA to $\mathrm{NH}_{3}$ emission change}

The discussion in the previous two subsections focuses on the response of SNA over China to past and anticipated future changes of $\mathrm{SO}_{2}$ and $\mathrm{NO}_{\mathrm{x}}$ emissions under the conditions of constant $\mathrm{NH}_{3}$ emissions from 2000 to 2015 . The 2006A case (Sect. 2) examines the impact of the potential high bias in the $\mathrm{NH}_{3}$ emission inventory for 2006 on simulated present-day SNA concentrations in China. In this subsection, we examine the sensitivity of SNA in 2015 to changes in $\mathrm{NH}_{3}$ emissions. Dong et al. (2010) suggested that the growth rate of $\mathrm{NH}_{3}$ emissions in China was stabilized at about $1.5 \%$ per year from 2000 to 2006. As China has not set up any policies to control $\mathrm{NH}_{3}$ emissions, we assume that $\mathrm{NH}_{3}$ emissions will increase at this rate from 2006 to 2015 . As a result, national total $\mathrm{NH}_{3}$ emissions will increase by $16 \%$ from 2006 to 2015 , which happens to be the same fractional increase as $\mathrm{NO}_{\mathrm{x}}$ emissions over this period. This forms a new sensitivity case referred to as 2015A, in which the emissions of $\mathrm{NO}_{\mathrm{x}}$ and $\mathrm{SO}_{2}$ are kept the same as in $2015 \mathrm{C}$.

Figure 12c shows the absolute difference (2015A minus 2006C) in annual mean mass concentrations of sulfate, nitrate, and TSNA due to the assumed simultaneous changes of $\mathrm{SO}_{2}, \mathrm{NO}_{\mathrm{x}}$, and $\mathrm{NH}_{3}$ emissions from 2006 to 2015. Sulfate decreases by about $13 \%$ over China in 2015A as compared to 2006C, which is similar to the magnitude of decrease found in $2015 \mathrm{C}$. Although the increase of $\mathrm{NH}_{3}$ emissions has no influence on sulfate, it results in a large enhancement of nitrate, reaching $34-46 \%$ or up to $7 \mu \mathrm{g} \mathrm{m}^{-3}$ over $\mathrm{NC}, \mathrm{SC}$, and SCB. Such an increase is even larger than the linear addition of the fractional increase of both $\mathrm{NO}_{\mathrm{x}}$ and $\mathrm{NH}_{3}$ emissions $(2 \times 16 \%$ $=32 \%)$. As discussed previously, this is due to the release of additional free $\mathrm{NH}_{3}$ to form $\mathrm{NH}_{4} \mathrm{NO}_{3}$ as a result of decreasing $\mathrm{SO}_{2}$ emissions and thus sulfate. Driven by the large increase of nitrate, TSNA shows an increase all over China. Compared to $2015 \mathrm{C}$, the benefits from $\mathrm{SO}_{2}$ and $\mathrm{NO}_{\mathrm{x}}$ emissions control in stabilizing or reducing SNA are more than offset by the same fractional increase of $\mathrm{NH}_{3}$ emissions. As shown in Fig. 13, the increase of $\mathrm{NH}_{3}$ emissions also leads to an increase of nitrate proportion in SNA. Analysis of the 2015A case indicates that $\mathrm{NH}_{3}$ is the key factor to determining SNA concentrations in China in the future given the anticipated reduction of $\mathrm{SO}_{2}$ emissions and increase of $\mathrm{NO}_{\mathrm{x}}$ emissions. $\mathrm{NH}_{3}$ emissions control needs to be enforced along with $\mathrm{SO}_{2}$ and $\mathrm{NO}_{\mathrm{x}}$ emissions control in mitigating SNA concentrations in China in the future.

\section{Conclusions}

The changes in ground-level mass concentrations and composition of SNA aerosols over China from 2000 to 2015 are simulated using the nested-grid GEOS-Chem model, based on anthropogenic emission changes of $\mathrm{SO}_{2}, \mathrm{NO}_{\mathrm{x}}$, and $\mathrm{NH}_{3}$ over the past and in the future driven by emissions control targets in the 11th and 12th FYP. We show that the model using 2006 emissions is able to simulate the spatial and seasonal distributions of SNA and its components over China. The model has very small biases of $-10 \%$ and $+6 \%$ in reproducing surface mass concentrations of sulfate and TSNA, respectively. Although simulated nitrate and ammonium concentrations correlate well with observations, the model has a large bias of about $+30 \%$ for nitrate, which is attributed mainly to overestimation of ammonia emissions in China used as model input.

We show that the mass concentration and composition of SNA aerosols differ by season and region as a result of the temporal and spatial variability in precursor emissions, oxidation rate, and deposition. The highest concentrations of all SNA species occur over NC, SC, and SCB where the precursor emissions are highest. Chemical oxidation rate is the dominant factor in determining SNA concentration levels and seasonality over $\mathrm{NC}$, whereas the controlling factors are emissions and wet deposition over SC and SCB. In the present-day case (2006C), sulfate is the dominant component of SNA over SC and SCB, while nitrate and sulfate contribute equally to SNA over NC.

From 2000 to 2006, $\mathrm{SO}_{2}$ and $\mathrm{NO}_{\mathrm{x}}$ emissions from China increased by $60 \%$ and $80 \%$, respectively. Total SNA mass 
concentration increased by about $60 \%$ all over China, most of which was driven by $\mathrm{SO}_{2}$ emission increase, except over $\mathrm{NC}$ where contribution of $\mathrm{NO}_{\mathrm{x}}$ emission increase was even larger. From 2006 to 2015, $\mathrm{SO}_{2}$ and $\mathrm{NO}_{\mathrm{x}}$ emissions from China will change by $-16 \%$ and $+16 \%$, respectively, based on the $\mathrm{SO}_{2}$ and $\mathrm{NO}_{\mathrm{x}}$ emissions control target set by the 12th FYP. Under constant $\mathrm{NH}_{3}$ emissions, sulfate will decrease linearly with $\mathrm{SO}_{2}$ emission changes, while nitrate will increase more than the percentage increase of $\mathrm{NO}_{\mathrm{x}}$ emissions as the decrease of sulfate releases free $\mathrm{NH}_{3}$ to make $\mathrm{NH}_{4} \mathrm{NO}_{3}$. TSNA concentrations will either increase or decrease across China, depending on the competition between sulfate reduction and nitrate increase. Over NC, TSNA concentrations will increase by $2 \%$, experiencing larger impacts from $\mathrm{NO}_{\mathrm{x}}$ emission increase, whereas they will decrease by $5 \%$ over $\mathrm{SCB}$ with larger effect from $\mathrm{SO}_{2}$ emissions decrease. Over SC, the two effects cancel out and there will be little change in TSNA concentrations from 2006 to 2015. This analysis suggests that the $\mathrm{SO}_{2}$ emissions control target set forth by the 12th FYP is effective in reducing SNA over $\mathrm{SC}$ and SCB, but not over NC, for which $\mathrm{NO}_{\mathrm{x}}$ emission control should be strengthened.

We also conducted a sensitivity study (2015A) in which $\mathrm{NH}_{3}$ emissions are allowed to increase by $+16 \%$ from 2006 to 2015 (the same percentage increase as $\mathrm{NO}_{\mathrm{x}}$ ). Nitrate will increase by more than $40 \%$, more than offsetting the benefit of $\mathrm{SO}_{2}$ emission reductions over all of China. This sensitivity analysis demonstrates the critical role of $\mathrm{NH}_{3}$ in regulating nitrate. The policy implication is that the effective strategy to control SNA and hence $\mathrm{PM}_{2.5}$ pollution over China should be based on improved understanding of current $\mathrm{NH}_{3}$ emissions in China and put more emphasis on controlling $\mathrm{NH}_{3}$ emissions in the future.

Our analysis is an attempt to understand the past and perceived-future response of atmospheric SNA aerosols to precursor emissions changes in China, and to give policy implications for emissions control. Given the uncertainties in estimating future precursor emissions in China, especially $\mathrm{NH}_{3}$ emissions, and the model's deficiency in accurately simulating individual components of SNA, our work cannot be taken as a prediction of future SNA levels in China. In particular, the model's overestimation of nitrate may cause an overprediction of the role of $\mathrm{NO}_{\mathrm{x}}$ emissions in determining SNA levels over NC, as reducing nitrate will reduce the sensitivity of SNA to $\mathrm{NO}_{\mathrm{x}}$ emissions. On the other hand, we may have underestimated the role of $\mathrm{NH}_{3}$ emissions in controlling SNA in the future, as the overestimation of nitrate indicates that the model already has too much $\mathrm{NH}_{3}$ in the present. Further work is clearly needed to construct careful projections of precursor emissions in the future and to improve the model's performance. More observations containing longer term SNA concentration changes are also needed.
Acknowledgements. This research was jointly supported by the CAS Strategic Priority Research Program (Grant No. XDA05100403) and the International Science \& Technology Cooperation Program of China (2010DFA21300). Y. Wang acknowledges additional funding from the National High Technology Research and Development Program of China (2009AA122005). We thank EANET for providing surface measurements.

Edited by: J. West

\section{References}

Adams, P. J. and Seinfeld, J. H.: Global concentrations of tropospheric sulfate, nitrate and ammonium aerosol simulated in a general circulation model, J. Geophys. Res., 104, 13791-13823, 1999.

Alexander, B., Hastings, M. G., Allman, D. J., Dachs, J., Thornton, J. A., and Kunasek, S. A.: Quantifying atmospheric nitrate formation pathways based on a global model of the oxygen isotopic composition $\left(\Delta^{17} \mathrm{O}\right)$ of atmospheric nitrate, Atmos. Chem. Phys., 9, 5043-5056, doi:10.5194/acp-9-5043-2009, 2009.

Ansari, A. S. and Pandis, S. N.: Response of inorganic PM to precursor concentrations, Environ. Sci. Technol., 32, 2706-2714, 1998.

Benkovitz, C. M., Scholtz, M. T., Pacyna, J., Tarrasón, L., Dignon, J., Voldner, E. C., Spiro, P. A., Logan, J. A., and Graedel, T. E.: Global gridded inventories of anthropogenic emissions of sulfur and nitrogen, J. Geophys. Res., 101, 29239-29253, doi:10.1029/96JD00126, 1996.

Bey, I., Jacob, D. J., Yantosca, R. M., Logan, J. A., Field, B. D., Fiore, A. M., Li, Q., Liu, H. Y., Mickley, L. J., and Schultz, M. G.: Global modeling of tropospheric chemistry with assimilated meteorology: Model description and evaluation, J. Geophys. Res., 106, 23073-23095, doi:10.1029/2001JD000807, 2001.

Binkowski, F. S. and Rpselle, S. J.: Models-3 Community Multiscale Air Quality (CMAQ) model aerosol component, 1, model description, J. Geophys. Res., 108, 4183, doi:10.1029/2001JD001409, 2003.

Bouwman, A. F., Lee, D. S., Asman, W. A. H., Dentener, F. J., Van der Hoek, K. W., and Olivier, J. G. J.: A global high-resolution emission inventory for ammonia, Global Biogeochem. Cy., 11, 561-587, doi:10.1029/97GB02266, 1997.

Chan, C. K. and Yao, X.: Air pollution in mega cities in China, Atmos. Environ., 42, 1-42, doi:10.1016/j.atmosenv.2007.09.003, 2008.

Chen, D., Wang, Y., McElroy, M. B., He, K., Yantosca, R. M., and Le Sager, P.: Regional CO pollution and export in China simulation by the high-resolution nested-grid GEOS-Chem model, Atmos. Chem. Phys., 9, 3825-3839, doi:10.5194/acp-9-3825-2009, 2009.

Clarisse, L., Clerbaux, C., Dentener, F., Hurtmans, D., and Choeur, P. F.: Global ammonia distribution derived from infrared satelliteobservations, Nature Geosci., 2, 479-483, doi:10.1038/ngeo551, 2009.

Cofala, J., Amann, M., Klimont, Z., Kupiainen, K., and HöglundIsaksson, L.: Scenarios of global anthropogenic emissions of air pollutants and methane until 2030, Atmos. Environ., 41, 84868499, doi:10.1016/j.atmosenv.2007.07.010, 2007. 
Dong, W., Xing, J., and Wang, S.: Temporal and spatial distribution of anthropogenic ammonia emissions in China: 1994-2006, Environ. Sci., 31, 1457-1463, 2010 (in Chinese).

EANET: Data report on the acid deposition in the East Asia region 2007, http://www.eanet.cc/product/index.html, 2008.

Feng, J. L., Guo, Z. G., Chan, C. K., and Fang, M.: Properties of organic matter in $\mathrm{PM}_{2.5}$ at Changdao Island, China - A rural site in the transport path of the Asian continental outflow, Atmos. Environ., 41, 1924-1935, 2007.

Fisher, J. A., Jacob, D. J., Wang, Q., Bahreini, R., Carouge, C. C., Cubison, M. J., Dibb, J. E., Diehl, T., Jimenez, J. L., Leibensperger, E. M., Lu, Z., Meinders, M. B. J., Pye, H. O. T., Quinn, P. K., Sharma, S., Streets, D. G., van Donkelaar, A., and Yantosca, R. M.: Sources, distribution and acidity of sulfate- ammonium aerosol in the Arctic in winter- spring, Atmos. Environ., 45, 7301-7318, 2011.

Fountoukis, C. and Nenes, A.: ISORROPIA II: a computationally efficient thermodynamic equilibrium model for $\mathrm{K}^{+}$ $\mathrm{Ca}^{2+}-\mathrm{Mg}^{2+}-\mathrm{NH}_{4}^{+}-\mathrm{Na}^{+}-\mathrm{SO}_{4}^{2-}-\mathrm{NO}_{3}^{-}-\mathrm{Cl}^{-}-\mathrm{H}_{2} \mathrm{O}$ aerosols, Atmos. Chem. Phys., 7, 4639-4659, doi:10.5194/acp-7-4639-2007, 2007.

Fountoukis, C., Racherla, P. N., Denier van der Gon, H. A. C., Polymeneas, P., Charalampidis, P. E., Pilinis, C., Wiedensohler, A., Dall'Osto, M., O'Dowd, C., and Pandis, S. N.: Evaluation of a three-dimensional chemical transport model (PMCAMx) in the European domain during the EUCAARI May 2008 campaign, Atmos. Chem. Phys., 11, 10331-10347, doi:10.5194/acp11-10331-2011, 2011.

Hagler, G. S. W, Bergin, M. H., Salmon, L. G., Yu, J. Z., Wan, E. C.H., Zheng, M., Zeng, L. M., Kiang, C. S., Zhang, Y. H., Lau, A. K. H., and Schauer, J. J.: Source areas and chemical composition of fine particulate matter in the Pearl River Delta region of China, Atmos. Environ., 40, 3802-3815, 2006.

He, K., Zhao, Q., Ma, Y., Duan, F., Yang, F., Shi, Z., and Chen, G.: Spatial and seasonal variability of $\mathrm{PM}_{2.5}$ acidity at two Chinese megacities: insights into the formation of secondary inorganic aerosols, Atmos. Chem. Phys., 12, 1377-1395, doi:10.5194/acp12-1377-2012, 2012.

Heald, C. L., Jacob, D. J., Park, R. J., Alexander, B., Fairlie, T. D., Yantosca, R. M., and Chu, D. A.: Transpacific transport of Asian anthropogenic aerosols and its impact on surface air quality in the United States, J. Geophys. Res., 111, D14310, doi:10.1029/2005JD006847, 2005.

Heald, C. L., J. L. Collett Jr., Lee, T., Benedict, K. B., Schwandner, F. M., Li, Y., Clarisse, L., Hurtmans, D. R., Van Damme, M., Clerbaux, C., Coheur, P.-F., Philip, S., Martin, R. V., and Pye, H. O. T.: Atmospheric ammonia and particulate inorganic nitrogen over the United States, Atmos. Chem. Phys., 12, 10295-10312, doi:10.5194/acp-12-10295-2012, 2012.

Hillamo, R., Allegrini, I., Sparapani, R., and Kerminen, V.-M.: Mass size distributions and precursor gas concentrations of major inorganic ions in Antarctic aerosol, Int. J. Environ. Anal. Chem., 71, 353-372, 1998.

Huang, C., Chen, C. H., Li, L., Cheng, Z., Wang, H. L., Huang, H. Y., Streets, D. G., Wang, Y. J., Zhang, G. F., and Chen, Y. R.: Emission inventory of anthropogenic air pollutants and VOC species in the Yangtze River Delta region, China, Atmos. Chem. Phys., 11, 4105-4120, doi:10.5194/acp-11-4105-2011, 2011.
Huang, X., Song, Y., Li, M., Li, J., Huo, Q., Cai, X., Zhu, T., Hu, M., and Zhang, H.: A high-resolution ammonia emission inventory in China, Global Biogeochem. Cy., 26, GB1030, doi:10.1029/2011GB004161, 2012.

Kim, J. Y., Song, C. H., Ghim, Y. S., Won, J. G., Yoon, S. C., Carmichael, G. R., and Woo, J.-H.: An investigation on $\mathrm{NH}_{3}$ emissions and particulate $\mathrm{NH}_{4}^{+}-\mathrm{NO}_{3}^{-}$formation in East Asia, Atmos. Environ., 40, 2139-2150, 2006.

Khoder, M. I.: Atmospheric conversion of sulfur dioxide to particulate sulfate and nitrogen dioxide to particulate nitrate and gaseous nitric acid in an urban area, Chemosphere, 49, 675-684, doi:10.1016/S0045-6535(02)00391-0, 2002.

Kharol, S. K., Martin, R. V., Philip, S., Vogel, S., Henze, D. K., Chen, D., Wang, Y., Zhang, Q., and Heald, C. L.: Persistent sensitivity of Asian aerosol to emissions of nitrogen oxides, Geophys. Res. Lett., doi:10.1002/grl.50234, in press, 2013.

Lamsal, L. N., Martin, R. V., Padmanabhan, A., van Donkelaar, A., Zhang, Q., Sioris, C. E., Chance, K., Kurosu, T. P., and Newchurch, M. J.: Application of satellite observations for timely updates to global anthropogenic $\mathrm{NO}_{\mathrm{x}}$ emissions inventories, Geophys. Res. Lett., 38, L05810, doi:10.1029/2010GL046476, 2011.

Leibensperger, E. M., Mickley, L. J., Jacob, D. J., Chen, W.-T., Seinfeld, J. H., Nenes, A., Adams, P. J., Streets, D. G., Kumar, N., and Rind, D.: Climatic effects of 1950-2050 changes in US anthropogenic aerosols - Part 1: Aerosol trends and radiative forcing, Atmos. Chem. Phys., 12, 3333-3348, doi:10.5194/acp-12-33332012, 2012a.

Leibensperger, E. M., Mickley, L. J., Jacob, D. J., Chen, W.-T., Seinfeld, J. H., Nenes, A., Adams, P. J., Streets, D. G., Kumar, N., and Rind, D.: Climatic effects of 1950-2050 changes in US anthropogenic aerosols - Part 2: Climate response, Atmos. Chem. Phys., 12, 3349-3362, doi:10.5194/acp-12-3349-2012, 2012 b.

Liu, H., Jacob, D. J., Bey, I., and Yantosca, R. M.: Constraints from $210 \mathrm{~Pb}$ and $7 \mathrm{Be}$ on wet deposition and transport in a global three-dimensional chemical tracer model driven by assimilated meteorological fields, J. Geophys. Res., 106, 1210912128, doi:10.1029/2000JD900839, 2001.

Lu, Z., Zhang, Q., and Streets, D. G.: Sulfur dioxide and primary carbonaceous aerosol emissions in China and India, 1996-2010, Atmos. Chem. Phys., 11, 9839-9864, doi:10.5194/acp-11-98392011, 2011.

Meng Z. and Seinfeld, J. H.: On the source of the submicrometer droplet mode of urban and regional aerosols, Aerosol Sci. Technol., 20, 253-265, doi:10.1080/02786829408959681, 1994.

Monn, C. and Schaeppi, G.: Concentrations of total suspended particulates, fine particles and their anionic compounds in ambient air and indoor air, Environ. Technol., 14, 869-875, 1993.

Mozurkewich. M.: The dissociation constant of ammonium nitrate and its dependence on temoerature, relative humidity and particle size, Atmos. Environ. A, 27, 261-270, 1993.

Park, R. J., Jacob, D. J., Field, B. D., Yantosca, R. M., and Chin, M.: Natural transboundary pollution influences on sulfate-nitrateammonium aerosols in the United States: Implications for policy, J. Geophys. Res., 109, D15204, doi:10.1029/2003JD004473, 2004.

Park, R. J., Jacob, D. J., Kumar, N., and Yantosca, R. M.: Regional visibility statistics in the United States: Natural and transboundary pollution influences, and implications for 
the Regional Haze Rule, Atmos. Environ., 40, 5405-5423, doi:10.1016/j.atmosenv.2006.04.059, 2006.

Pathak, R. K., Wu, W. S., and Wang, T.: Summertime $\mathrm{PM}_{2.5}$ ionic species in four major cities of China: nitrate formation in an ammonia-deficient atmosphere, Atmos. Chem. Phys., 9, 17111722, doi:10.5194/acp-9-1711-2009, 2009.

Pinder, R. W. and Adams, P. J.: Ammonium emission controls as a cost-effective strategy for reducing atmospheric particulate matter in the east Unite States, Environ. Sci. Tchenol., 41, 380-386, 2007.

Pye, H. O., Liao, H., Wu, S., Mickley, L. J., Jacob, D. J., Henze, D. K., and Seinfeld, J. H.: Effect of changes in climate and emissions on future sulfate-nitrate-ammonium aerosol levels in the United States, J. Geophys. Res., 114, D01205, doi:10.1029/2008JD010701, 2009.

Querol, X., Alastuey, A., Ruiz, C. R., Artinano, B., Hansson, H. C., Harrison, R. M., Buringh, E., ten Brink, H. M., Lutz, M., Bruckmann, P., Straehl, P., and Schneider, J.: Speciation and origin of $\mathrm{PM}_{10}$ and $\mathrm{PM}_{2.5}$ in selected European cities, Atmos. Environ., 38, 6547-6555, 2004.

Seinfeld, J. H. and Pandis, S. N.: Atmospheric Chemistry and Physics: From Air Pollution to Climate Change, John Wiley, Hoboken, NJ, 1998.

Shephard, M. W., Cady-Pereira, K. E., Luo, M., Henze, D. K., Pinder, R. W., Walker, J. T., Rinsland, C. P., Bash, J. O., Zhu, L., Payne, V. H., and Clarisse, L.: TES ammonia retrieval strategy and global observations of the spatial and seasonal variability of ammonia, Atmos. Chem. Phys., 11, 10743-10763, doi:10.5194/acp-11-10743-2011, 2011.

Smith, S. J., Pitcher, H., and Wigley, T. M. L.: Global and regional anthropogenic sulfur dioxide emissions, Global Planet. Change, 29, 99-119, 2001.

Smith, S. J., van Aardenne, J., Klimont, Z., Andres, R. J., Volke, A., and Delgado Arias, S.: Anthropogenic sulfur dioxide emissions: 1850-2005, Atmos. Chem. Phys., 11, 1101-1116, doi:10.5194/acp-11-1101-2011, 2011.

Streets, D. G., Bond, T. C., Carmichael, G. R., Fernandes, S. D., Fu,Q., He, D., Klimont, Z., Nelson, S. M., Tsai, N. Y., Wang, M. Q., Woo, J.-H., and Yarber, K. F.: An inventory of gaseous andprimary aerosol emissions in Asia in the year 2000, J. Geophys. Res., 108, 8809, doi:10.1029/2002JD003093, 2003.

Tsimpidi, A. P. and Karydis, V. A.: Response of inorganic fine particulate matter to emission changes of sulfur dioxide and ammonia: the easten united states as a case study, Air Waste Manage. Assoc., 57, 1489-1498, doi:10.3155/1047-3289.57.12.1489, 2007.

Tsimpidi, A. P. and Karydis, V. A.: Response of fine particulate matter to emission changes of oxidies of nitrogen and anthropogenic volatile organic compounds in the Eastern United States, Air Waste Manage. Assoc., 58, 1463-1473, doi:10.3155/10473289.58.11.1463, 2008.

van Donkelaar, A., Martin, R. V., and Park, R. J.: Estimating ground-level $\mathrm{PM}_{2.5}$ using aerosol optical depth determined from satellite remote sensing, J. Geophys. Res., 111, D21201, doi:10.1029/2005JD006996, 2006.

van Donkelaar, A., Martin, R. V., Leaitch, W. R., Macdonald, A. M., Walker, T. W., Streets, D. G., Zhang, Q., Dunlea, E. J., Jimenez, J. L., Dibb, J. E., Huey, L. G., Weber, R., and Andreae, M. O.: Analysis of aircraft and satellite measurements from the Inter- continental Chemical Transport Experiment (INTEX-B) to quantify long-range transport of East Asian sulfur to Canada, Atmos. Chem. Phys., 8, 2999-3014, doi:10.5194/acp-8-2999-2008, 2008.

van Donkelaar, A., Martin, R. V., Brauer, M., Kahn, R., Levy, R., Verduzco, C., and Villeneuve, P. J.: Global estimates of ambient fine particulate matter concentrations from satellite-based aerosol optical depth: development and application, Environ. Health Perspect., 118, 847-855, 2010.

Wang, X., Wang, Y. X., Hao, J. M., Kondo, Y., Irwin, M., Munger, J. W., and Zhao, Y. J.: Top-down estimate of China's black carbon emissions using surface observations: sensitivity to observation representativeness and transport model error, J. Geophys. Res., submitted, 2012.

Wang, Y., Jacob, D. J., and Logan, J. A.: Global simulation of tropospheric $\mathrm{O}_{3}-\mathrm{NO}_{\mathrm{x}}$-hydrocarbon chemistry, 1, model formulation, J. Geophys. Res., 103, 10713-10726, 1998.

Wang, Y., Zhuang, G., Zhang, X., Huang, K., Xu, C., Tang, A., Chen, J., and An, Z.: The ion chemistry, seasonal cycle, and sources of $\mathrm{PM}_{2.5}$ and TSP aerosol in shanghai, Atmos. Environ., 40, 2935-2952, 2006.

Wang, Y. X., McElroy, M. B., Jacob, D. J., and Yantosca, R. M.: A nested grid formulation for chemical transport over Asia: Applications to CO, J. Geophys. Res., 109, D22307, doi:10.1029/2004JD005237, 2004.

Watson, J. G.: Critical review-visibility: science and regulation, J. Air Waste Manage. Assoc., 52, 628-713, 2002.

Wesely, M. L.: Parameterization of surface resistance to gaseous dry deposition in regional-scale numerical models, Atmos. Environ., 23, 1293-1304, 1989.

Yang, F., Tan, J., Zhao, Q., Du, Z., He, K., Ma, Y., Duan, F., Chen, G., and Zhao, Q.: Characteristics of $\mathrm{PM}_{2.5}$ speciation in representative megacities and across China, Atmos. Chem. Phys., 11, 5207-5219, doi:10.5194/acp-11-5207-2011, 2011.

Yang, H., Yu, J. Z., Ho, S. S. H., Xu, J. H., Wu, W. S., Wan, C. H., Wang, X. D., Wang, X. R., and Wang, L. S.: The chemical composition of inorganic and carbonaceous materials in $\mathrm{PM}_{2.5}$ in Nanjing, China, Atmos. Environ., 39, 3735-3749, 2005.

Yang, L.: Characterization and source apportionment of PM2.5 andits impact on visibility in Jinan, $\mathrm{PhD}$ thesis, Shandong University, Jinan, 2008 (in Chinese).

Yao, X., Chan, C. K., Fang, M., Cadle, S., Chan, T., Mulawa, P., He, K., and Ye, B.: The water-soluble ionic composition of $\mathrm{PM}_{2.5}$ in Shanghai and Beijing, China, Atmos. Environ., 36, 4223-4234, 2002.

Ye, B., Ji, X., Yang, H., Yao, X., Chan, C. K., Cadle, S. H., Chan, T., and Mulawa, P. A., Concentration and chemical composition of $\mathrm{PM}_{2.5}$ in Shanghai for a 1-year period, Atmos. Environ., 37, 499-510, 2002.

Zhang, L., Jacob, D. J., Knipping, E. M., Kumar, N., Munger, J. W., Carouge, C. C., van Donkelaar, A., Wang, Y. X., and Chen, D.: Nitrogen deposition to the United States: distribution, sources, and processes, Atmos. Chem. Phys., 12, 4539-4554, doi:10.5194/acp-12-4539-2012, 2012.

Zhang, Q., Streets, D. G., He, K., Wang, Y. X., Richter, A., Burrows, J. P., Uno, I., Jang, C. J., Chen, D., Yao, Z., and Lei, Y.: $\mathrm{NO}_{\mathrm{x}}$ emission trends for China, 1995-2004: the view from the ground and the view from space, J. Geophys. Res., 112, D22306, doi:10.1029/2007JD008684, 2007. 
Zhang, Q., Streets, D. G., Carmichael, G. R., He, K. B., Huo, H., Kannari, A., Klimont, Z., Park, I. S., Reddy, S., Fu, J. S., Chen, D., Duan, L., Lei, Y., Wang, L. T., and Yao, Z. L.: Asian emissions in 2006 for the NASA INTEX-B mission, Atmos. Chem. Phys., 9, 5131-5153, doi:10.5194/acp-9-5131-2009, 2009.

Zhang, X. Y., Wang, Y. Q., Niu, T., Zhang, X. C., Gong, S. L., Zhang, Y. M., and Sun, J. Y.: Atmospheric aerosol compositions in China: spatial/temporal variability, chemical signature, regional haze distribution and comparisons with global aerosols, Atmos. Chem. Phys., 12, 779-799, doi:10.5194/acp12-779-2012, 2012.

Zhang, Y., Dore, A. J., Ma, L., Liu, X. J., Ma, W. Q., Cape, J. N., and Zhang, F. S.: Agricultural ammonia emissions inventory and spatial distribution in the North China Plain, Environ. Pollut., 158, 490-501, doi:10.1016/j.envpol.2009.08.033, 2010.
Zhao, Q., He, K., Rahn, K. A., Ma, Y., Jia, Y., Yang, F., Duan, F., Lei, Y., Chen, G., Cheng, Y., Liu, H., and Wang, S.: Dust storms come to Central and Southwestern China, too: implications from a major dust event in Chongqing, Atmos. Chem. Phys., 10, 26152630, doi:10.5194/acp-10-2615-2010, 2010.

Zhao, Y., Wang, S. X., Duan, L., Lei, Y., Cao, P. F., and Hao, J. M.: Primary air pollutant emissions of coal-fired power plants in China: current status and future prediction, Atmos. Environ., 42, 8442-8452, 2008.

Zhao, Y., Duan, L., Lei, Y., Xing, J., Nielsen, C. P., and Hao, J.: Will PM control undermine China's efforts to reduce soil acidification?, Environ. Pollut., 159, 2726-2732, 2011. 